\title{
Relevance of Biomarkers Currently in Use or Research for Practical Diagnosis Approach of Neonatal Early-Onset Sepsis
}

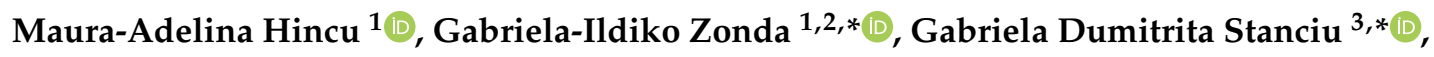 \\ Dragos Nemescu ${ }^{1,2}$ (D) and Luminita Paduraru 1,2 (D) \\ 1 Department of Mother and Child Care, "Grigore T. Popa” University of Medicine and Pharmacy, \\ 16 Universității Street, 700115 Iași, Romania; maurahancu@gmail.com (M.-A.H.); \\ dnemescu@yahoo.com (D.N.); luminita.paduraru@gmail.com (L.P.) \\ 2 "Cuza-Vodă" Clinical Hospital of Obstetrics and Gynecology, 34 Cuza-Vodă Street, 700038 Iași, Romania \\ 3 Center for Advanced Research and Development in Experimental Medicine (CEMEX), \\ "Grigore T. Popa" University of Medicine and Pharmacy, 16 Universității Street, 700115 Iași, Romania \\ * Correspondence: ildikozonda@yahoo.com (G.-I.Z.); gabriela-dumitrita.s@umfiasi.ro (G.D.S.)
}

Received: 4 November 2020; Accepted: 17 December 2020; Published: 20 December 2020

\begin{abstract}
Neonatal early-onset sepsis (EOS) is defined as an invasive infection that occurs in the first $72 \mathrm{~h}$ of life. The incidence of EOS varies from $0.5-2 \%$ live births in developed countries, up to $9.8 \%$ live births in low resource settings, generating a high mortality rate, especially in extremely low birth weight neonates. Clinical signs are nonspecific, leading to a late diagnosis and high mortality. Currently, there are several markers used for sepsis evaluation, such as hematological indices, acute phase reactants, cytokines, which by themselves do not show acceptable sensitivity and specificity for the diagnosis of EOS in neonates. Newer and more selective markers have surfaced recently, such as presepsin and endocan, but they are currently only in the experimental research stages. This comprehensive review article is based on the role of biomarkers currently in use or in the research phase from a basic, translational, and clinical viewpoint that helps us to improve the quality of neonatal early-onset sepsis diagnosis and management.
\end{abstract}

Keywords: early-onset sepsis; newborn; biomarker; acute phase reactant; cytokine; endocan; presepsin

\section{Relations between Prevalence, Clinical Aspects, and Risk Factors of Neonatal Early-Onset Sepsis}

Neonatal sepsis (NS) is one of the most challenging pathologies for the practitioner. This disease frequently leads to severe consequences for the newborn: post infectious encephalopathy, seizures, ventriculomegaly, hydrocephalus, encephalomalacia, brain infarction, neurodevelopmental delay, and sensorial deficits. NS is diagnosed as an infection occurring during the first month of life with clinical signs varying from subtle to severe systemic disease, shock and multisystem organ failure [1-3]. It may be acquired from the mother, during intrauterine life, transmitted to the fetus mainly in the last trimester, or acquired from the health care staff later, after birth. No clinical sign is specific only for NS, which makes the clinical diagnosis difficult, uncertain, and raises dilemmas regarding appropriate treatment and ethical decisions, especially in extremely low birth weight (ELBW) newborns [1].

Depending on the time of onset, NS has been divided into early-onset sepsis (EOS) and late-onset sepsis (LOS). EOS typically represents an infection that presents itself within the first 3 days of life $(<72 \mathrm{~h})$, but some researchers extend this limit up to the first week of life [4-7]. LOS is described as an infection occurring after the fourth or seventh day of life within the neonatal period [8-10]. EOS is considered as a maternal-fetal infection and LOS is mainly considered as hospital acquired. 
The incidence of EOS ranges between 1-2\%o live births [11] with a lower value in developed countries, according to some authors (0.5-1\%o) [12-14]. However, there are some small hospital-based studies that report an incidence for EOS as high as $9.8 \%$ o $[15,16]$. This variation may be due to different gestational ages (GA) included in statistics, as very low birth weight (VLBW) and extremely low birth weight (ELBW) neonates are at a greater risk for EOS, with rates up to $20 \%[8,16]$. The overall mortality rate is up to $24.4 \%$, but can be as high as $54 \%$ in infants between 22 to 24 weeks of gestation and $30 \%$ between 25 to 28 weeks of gestation $[17,18]$. EOS added to threshold survival limit can raise important challenges for neonatologists either for diagnostics, treatment and also ethical dilemmas [19].

There are several risk factors for a neonate to develop EOS and the most important are listed below $[1,2,20]$ (Table 1). Their importance consists of anticipating the probability of developing EOS, according to several calculated scores that include clinical signs and biochemical markers [21,22]. Inadequate or unavailable prenatal care leads to difficult identification of risk factors and EOS can occur as an unexpected neonatal emergency. Despite the abundance of research in the field of neonatal infection in the last few decades, a marker or test used in diagnosis of every case has not yet been developed. In neonates with risk factors and clinical suspicion of EOS, currently used biomarkers have insufficient predictive performance and confirmation of diagnosis by positive cultures is not always possible in a timely manner. Therefore, at present, there is no international consensus concerning which biomarker or combination of tests is best to accurately diagnose neonates with EOS [23].

Table 1. Risk factors for neonatal early-onset sepsis (EOS).

\begin{tabular}{ccc}
\hline Maternal Risk Factors & Neonatal Risk Factors & References \\
\hline Chorioamnionitis & & {$[1,24]$} \\
Premature rupture of membranes/Preterm pregnancy & Preterm newborn & {$[2,20,23]$} \\
with gestational age of $<37$ weeks & Low birth weight & {$[1,11]$} \\
Prolonged rupture of membranes even at term $(>18 \mathrm{~h})$ & Fetal distress & {$[14,25]$} \\
Intrapartum maternal fever $\geq 38^{\circ} \mathrm{C}$ & Low APGAR score & {$[15,20]$} \\
Maternal group B streptococcal colonization $(\mathrm{GBS})$ & Multiple pregnancies & {$[4,5,7]$} \\
Positive bacteriuria Inadequate intrapartum & Intensive resuscitation of the & {$[2,5]$} \\
antibiotic prophylaxis & newborn & {$[10]$} \\
A history of a previous infant with Gram negatives & & {$[8]$} \\
pathogens infection & & \\
\hline
\end{tabular}

Apgar is a quick test performed on a baby at 1 and 5 minutes after birth. A backronym for APGAR was coined in the United States as a mnemonic learning aid: Appearance (skin color), Pulse (heart rate), Grimace (reflex irritability), Activity (muscle tone), and Respiration.

For years, extensive research has focused on the classification of sepsis since this condition is a syndrome with a heterogeneous disease state. In this paper, we sought to highlight the relevance of biomarkers in rapid, sensitive, and specific neonatal early-onset sepsis diagnosis, with the aim of reinstating health, limiting hospitalization, and optimizing results oriented towards personalized therapies.

\section{Material and Methods}

This review paper provides a comprehensive overview focused on biomarkers currently in use or research from a basic, translational, and clinical viewpoint that helps us to improve the quality of neonatal early-onset sepsis diagnosis and management. We searched for reviews and original articles discussing the biomarkers for neonatal EOS diagnosis. The publications were collected from various independent databases including PubMed, Elsevier, Cochrane, Embase, Web of Science and Google Scholar, using the following keywords: "newborn", "EOS", “NS", "biological markers", "endocan", "presepsin", "acute phase reactants", and "cytokines" for the search. We reviewed the last and most accurate data from the literature, presented as reviews and original articles covering the period 1 January 2015 to 31 July 2020 that respect the Quadras-2 criteria, to identify the best biomarkers for the diagnosis of neonatal EOS. Moreover, since recent biomarkers were not included in reviews or 
meta-analysis, we aim to evaluate their role as well as a potential future practical tool of EOS diagnosis in neonates. Only papers in the English language from 2015 to 2020 were included, resulting in a total of 210 articles, based on the following criteria: data were addressed to all categories of newborns, term and preterm (gestational age from 24 to 42 weeks); papers covered NS or EOS; biomarkers were assessed either quantitatively or qualitatively; reviews were based on original articles, meta-analysis or/and randomized control studies and published in extenso. Letters to the editor, abstracts, studies that concerned only LOS or NS in general, without distinction between EOS and LOS, were not considered. After applying the key words and applying the above-mentioned filters, 28 papers remained to be studied and summarized (Figure 1).

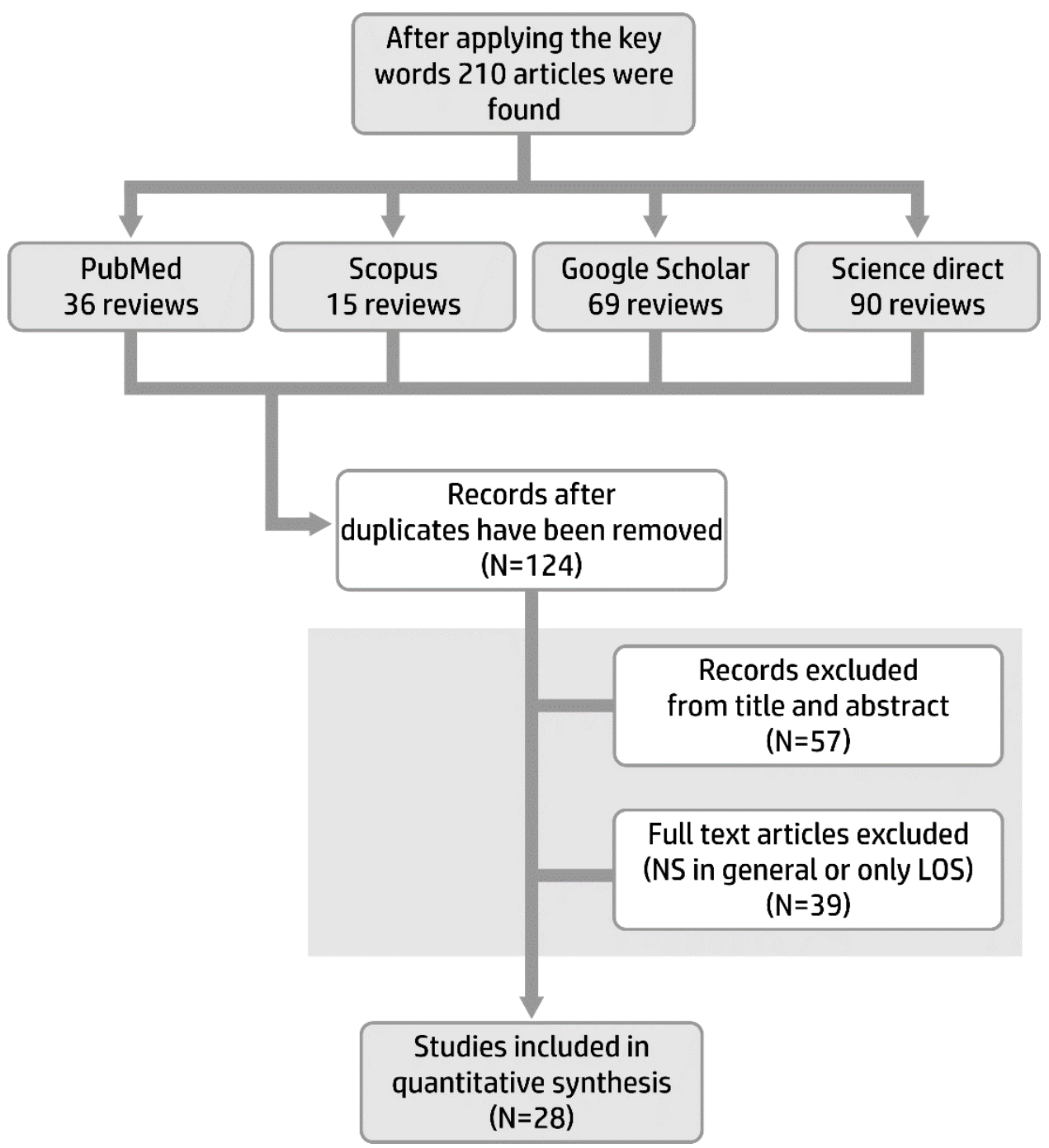

Figure 1. Flowchart of the selection process of the review articles.

After critical reading of the selected articles, we observed that some potential biomarkers were mentioned, but they have not been extensively studied in any review or meta-analysis yet. For these, we assessed relevant data reported as original articles based on cohort studies or randomized control studies.

\section{Biomarkers Commonly Used or Under Consideration for EOS Diagnosis in Neonates}

The ideal marker for infection should be valuable for establishing the diagnosis, as well as for predicting the outcome and for evaluation of the response to treatment; concomitantly, it should be easy to quantify and available for routine clinical use [26-28]. 
To date, several biomarkers (Figure 2) have been studied and used, many of them for research purposes only, as the necessary techniques and devices are not available in every clinical unit in a timely manner (Table 2).

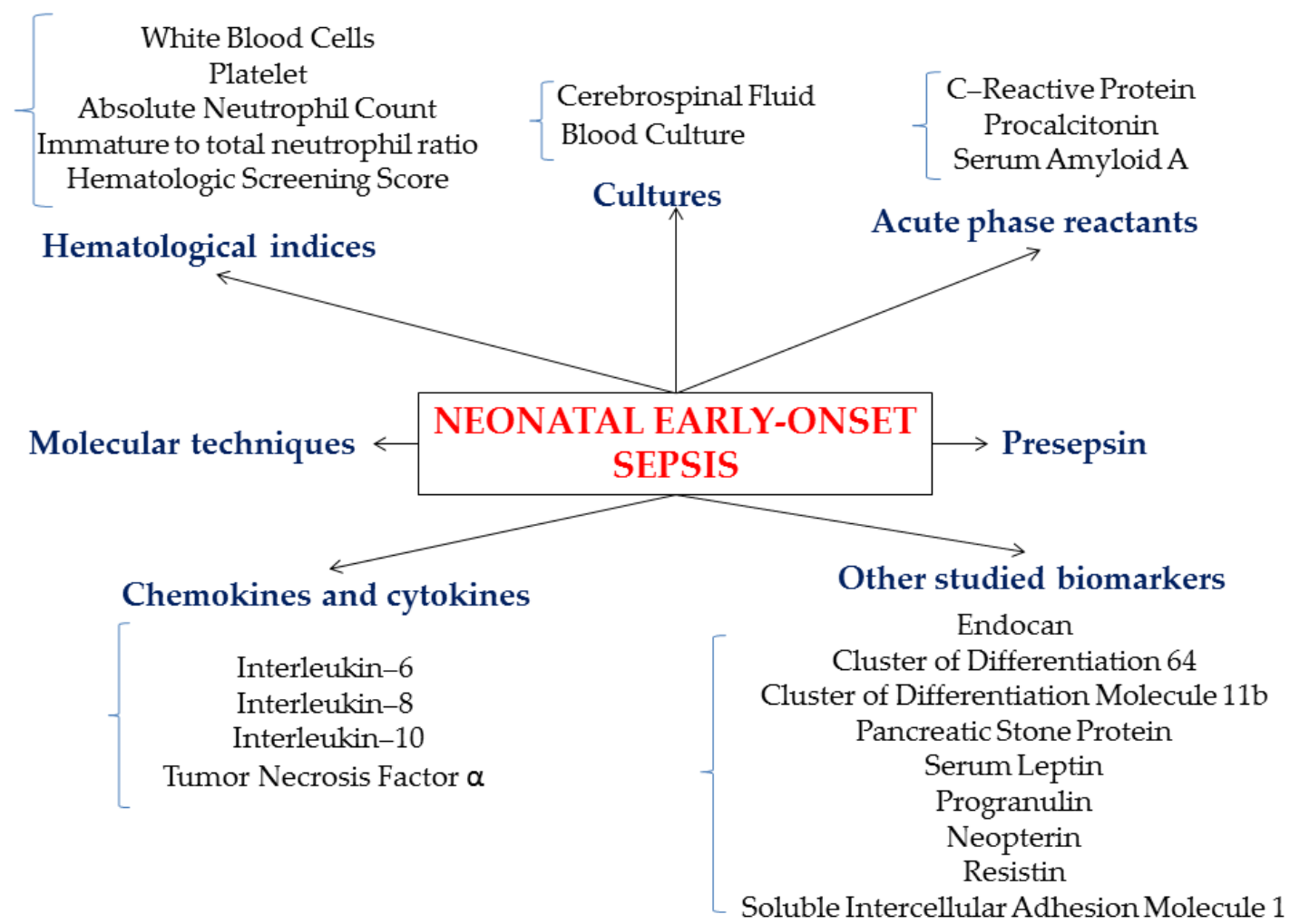

Figure 2. Schematic representation of common and developing biomarkers for neonatal early-onset sepsis.

Table 2. Currently used biomarkers for sepsis diagnosis in neonates.

\begin{tabular}{ccccccc}
\hline Marker & Cut-Off Value & $\begin{array}{c}\text { Sensitivity } \\
\mathbf{( \% )}\end{array}$ & $\begin{array}{c}\text { Specificity } \\
\mathbf{( \% )}\end{array}$ & PPV (\%) & NPV (\%) & Ref. \\
\hline White Blood Cells & $20,000 / \mathrm{mm}^{3}<5000 / \mathrm{mm}^{3}$ & 59.5 & 79.6 & 52 & 86.1 & {$[29]$} \\
C-Reactive Protein & $10 \mathrm{mg} / \mathrm{L}$ & 49 & 91 & 73 & 77 & {$[30]$} \\
Procalcitonin & $2.5 \mathrm{ng} / \mathrm{mL}$ & 75 & 83 & $\mathrm{NA}$ & $\mathrm{NA}$ & {$[31]$} \\
\hline & $100 \mathrm{pg} / \mathrm{mL}$ & 95.83 & 87.50 & 92 & 93.33 & {$[32]$} \\
& $181 \mathrm{pg} / \mathrm{mL}$ & 80.1 & 85.7 & 84.6 & 81.8 & {$[32]$} \\
Interleukin-6 & $60 \mathrm{pg} / \mathrm{mL}$ & 54 & 100 & 100 & 59 & {$[30]$} \\
& $10-150 \mathrm{pg} / \mathrm{mL}$ & $75-87$ & $50-82$ & 92 & 52 & {$[33]$} \\
& $60 \mathrm{pg} / \mathrm{mL}$ & 54 & 100 & 100 & 59 & {$[34]$} \\
\hline & $60 \mathrm{pg} / \mathrm{mL}$ & 95 & 10 & 97 & 10 & {$[32]$} \\
Interleukin-8 & $300 \mathrm{pg} / \mathrm{mL}$ & 91 & 93 & 91 & 97 & {$[30]$} \\
& $70 \mathrm{pg} / \mathrm{mL}$ & 92 & 70 & 65 & 93 & {$[34]$} \\
& $60-300 \mathrm{pg} / \mathrm{mL}$ & 90 & $75-100$ & 78 & 88 & {$[33]$} \\
\hline
\end{tabular}

PPV (\%), positive predictive value; NPV (\%), negative predictive value.

\subsection{Cultures}

\subsubsection{Blood Culture}

Clinical sepsis (infant with clinical signs, but negative cultures) is much more common, especially in EOS cases $[35,36]$. However, the current gold standard method for confirmation of sepsis in newborns with risk factors, clinical suspicion and abnormal test results remains the identification of the pathogenic 
organism from a normally sterile site (blood or cerebrospinal fluid) [25,35]. Classically, blood culture results take up to $72 \mathrm{~h}$, but the introduction of automated systems that detect the presence of growth from

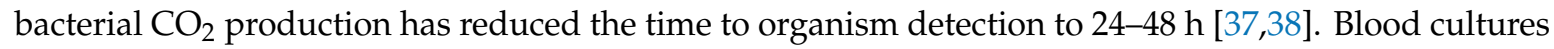
have high sensitivity and specificity for detecting significant bacteremia ( $95 \%$ and $99 \%$, respectively), even in very small samples of only $0.2 \mathrm{~mL}$ of blood, providing that a blood to total broth dilution of minimum $10 \%$ is maintained [39]. When neonatal EOS is suspected, blood cultures are usually obtained on the first day of life, but less than $1 \%$ come back positive [40]. In other words, the overwhelming majority of blood cultures sampled from newborns evaluated with risk factors or clinical signs of EOS are negative [9,38]. The administration of intrapartum antibiotic prophylaxis in mothers with either group B streptococcus colonization or suspected amnionitis originating from any cause can reduce the ability to detect bacteremia in newborns [27,37]. The volume of the sample might also play a part, as ideally 1-3 mL of blood should be obtained, and this is most often extremely difficult, if not impossible in ELBW infants. Organism density is another factor that may influence the chance of pathogen detection in the bloodstream. In infants with low very levels of bacteremia $(<4$ colony forming units (cfu)/mL), $1 \mathrm{~mL}$ samples are required to ensure a high sensitivity, whereas as little as $0.5 \mathrm{~mL}$ may be enough to detect moderate and high grade bacteremia (more than $10 \mathrm{cfu} / \mathrm{mL}$ ) [39]. Brown et al. [41] found that only $0.25 \mathrm{~mL}$ of placental blood seeded with $>10 \mathrm{cfu} / \mathrm{mL}$ Escherichia coli (E. coli) or group B streptococcus was sufficient yield a positive culture [39].

Modern continuous monitoring blood culture systems rely on blood culture time to positivity (TTP), which correlates inversely proportional to bacterial density and aids in clinical interpretation of the results. In the case of true pathogenic bacteria median, TTP is 9-18 $\mathrm{h}$ in neonatal sepsis [42-45]. For group B streptococcus and E. coli, $96 \%$ up to $100 \%$ of cultures are positive by $36 \mathrm{~h}[42,43,45]$. On the other hand, for coagulase negative staphylococci, which are almost always a contaminant, TTP can be as long as $48 \mathrm{~h}[42,46]$.

Molecular assays (conventional and real-time polymerase chain reaction (PCR) have the advantage of producing very rapid results, and have proven useful as "add-on" tests, but cannot replace blood cultures as the standard of diagnosis of neonatal sepsis [47,48].

\subsubsection{Cerebrospinal Fluid}

Approximately $40 \%$ of neonatal EOS cases caused by invasive group B streptococcal infection are associated with meningitis, with E. coli as the second most common pathogen [14]. Confirmation of meningitis requires sampling of a cerebrospinal fluid (CSF) specimen by lumbar puncture (LP) for culture, Gram stain, white blood cells count (WBC), glucose and protein levels [37]. However, in asymptomatic infants who are being evaluated for EOS based on maternal risk factors, it is appropriate to defer an LP. Nevertheless, all infants with positive culture proven EOS should undergo an LP [14].

The diagnosis of neonatal meningitis in the context of EOS is challenging even when an LP is performed. The difficulties in the interpretation of the results may decrease the benefit of the procedure relative to the risk of potentially severe associated complications (spinal hemorrhage and/or hematoma [49], osteomyelitis [50], brain herniation [51]). Antepartum or empirical antibiotic therapy for suspected EOS prior to LP may result in false negative CSF culture even when neonatal meningitis is present. According to Kanegaye et al. [52], complete sterilization of CSF Neisseria meningitidis (N. meningitides) and Streptococcus pneumonia (S. pneumonia) was documented within $2 \mathrm{~h}$ and $4 \mathrm{~h}$ of antimicrobial therapy, respectively. In such circumstances, the diagnosis of meningitis relies on other CSF parameters, but their reference ranges vary with gestational/postnatal age, and can also be altered in traumatic LPs, when the sample is contaminated with blood [53,54]. Studies that included term, near-term and preterm infants found that meningitis can occur in the presence of normal levels of CSF glucose, protein and WBC counts [55], but also even when a combination of these altered parameters (using as cut-off values $25 \mathrm{WBC}$ cells $/ \mu \mathrm{L}$, glucose concentration $<10 \mathrm{mg} / \mathrm{dL}$ and protein 
level $>250 \mathrm{mg} / \mathrm{dL}$, with a 164-fold increase in the odds of having a positive CSF culture) is used to "rule in" meningitis, less than $1 / 5$ of infants with positive CSF culture are diagnosed [56].

Even though in approximately $20 \%$ of newborns with proven meningitis, no bacteria are visualized on the Gram stain, the assay may still be useful for the diagnosis. In bacterial meningitis, the WBC concentration is usually elevated with neutrophilic pleocytosis, but in Listeria monocytogenes (L. monocytogenes) meningitis, a mononuclear cellular response is characteristic [37].

Due to the challenges of interpreting CSF parameters to diagnose neonatal meningitis, to increase the reliability of the CSF culture, the LP should be performed prior to administration of empirical antibiotics. If antimicrobial therapy has already been initiated, the clinician should maintain a high suspicion of the possibility of meningitis even in a neonate with negative CSF culture [14].

\subsection{Hematological Indices}

\subsubsection{White Blood Cells (WBCs)}

The WBC limits in the diagnosis of sepsis are usually below $5000 / \mathrm{mm}^{3}$ or over $30,000 / \mathrm{mm}^{3}$ [15]. Sharma et al. [57] claimed that values under $5000 / \mathrm{mm}^{3}$ for WBCs have a high specificity (91\%) regarding sepsis diagnosis, but the main weaknesses are the low sensitivity $(29 \%)$ and the need for correlation with the GA. If there is a viral infection with enterovirus, herpes simplex virus (HSV) or human parechovirus $(\mathrm{HPeV})$, the significance of WBCs becomes questionable, as its value either remains stable or a mild leucopenia occurs [28]. Two articles have highlighted that leucopenia (WBCs $<5000 / \mathrm{mm}^{3}$ at more than $4 \mathrm{~h}$, likelihood ratio of 81 ) is more suggestive for sepsis than leukocytosis (WBCs $>20,000 / \mathrm{mm}^{3}$ at more than $4 \mathrm{~h}$, likelihood ratio of 0.16 ) [18,58]. Another disadvantage of WBCs resides in the fact that the number of WBCs increases late after the onset of sepsis; hence, multiple studies have recommended obtaining a sample after 4 to $6 \mathrm{~h}$ from stimulation $[15,18,59]$. WBCs require dynamic follow up and they are more useful in ruling out an infection than in diagnosing it. There are controversies concerning specificity and the positive predictive value (PPV) for WBCs among authors [15,57]. Sharma et al. [57] stated that the positive predictive value (PPV) and negative predictive value (NPV) are both low for WBCs. The study by Tam et al. [58] affirmed a low PPV (36\%) but a high NPV (94\%) and emphasizes that it is better to associate the value of WBCs with postnatal age as its level is more accurate over time.

\subsubsection{Platelet (PLT)}

PLT and mean platelet volume (MPV) have a low sensitivity and specificity in the diagnosis of EOS [15]. Values of MPV greater than 8.6 FL, with a high sensitivity and specificity $(97.14 \%$ and $100 \%$, respectively), are considered efficient in the diagnosis of EOS [27]. Increased MPV values are found in respiratory distress syndrome, which makes the interpretation of PLT and MPV difficult in the context of added EOS. Thus, these parameters play only a suggestive role in the diagnosis of NS [28].

\subsubsection{Absolute Neutrophil Count (ANC)}

Gestational and postnatal age, delivery method, altitude, maternal fever and hypertension, fetal asphyxia, meconium aspiration, periventricular hemorrhage, reticulocytosis, hemolytic disease and pneumothorax affect ANC values, limiting its use in EOS $[15,28,58]$. It is recommended to obtain a sample for ANC after 6 to $12 \mathrm{~h}$ of life in order to reveal a systemic inflammatory response in term newborns [15,27], which importantly delays therapeutic decisions. The peak level of neutrophils depends on GA (between 12 to $24 \mathrm{~h}<28 \mathrm{GA}$ and between 6 to $8 \mathrm{~h}>28 \mathrm{GA}$ ) [15,58]. Neutropenia (ANC $<1000 / \mathrm{mm}^{3}$ at more than $4 \mathrm{~h}$, likelihood ratio 15 ) is more frequently associated with EOS, having a higher specificity than neutrophilia (ANC $>10,000 / \mathrm{mm}^{3}$ at more than $4 \mathrm{~h}$, likelihood ratio of 0.31), being less helpful in diagnosing EOS [15,27,57,58]. Distinct values for neutropenia were proposed: ANC $<1800 / \mathrm{mm}^{3}$ at birth, $<7800 / \mathrm{mm}^{3}$ at $12-14 \mathrm{~h}$ after birth and at $72 \mathrm{~h} \mathrm{ANC}<1800 / \mathrm{mm}^{3}$ for term and late preterm infants [15], ANC $<1000 / \mathrm{mm}^{3}$ at $4 \mathrm{~h}$ after birth [58]. Furthermore, there are some specific situations such as active labor and female gender that lead to neutrophilia in the absence of 
infection, affecting the immature to total neutrophil ratio and leading to a high false positive predictive value $[37,58]$. Nevertheless, there are some factors such as maternal hypertension, gestational age and delivery method (cesarean delivery without labor) that can decrease the ANC levels, leading to a false negative predictive value $[15,28]$.

\subsubsection{Immature to Total Neutrophil Ratio (I:T Ratio)}

Out of all hematological markers, the I:T ratio is the most sensitive indicator of NS, but this parameter also varies with GA and postnatal age $[15,27]$. Classically, I:T ratio $>0.2$ is criteria for suspected EOS with high sensitivity (90\%), NPV (98-99\%), but low PPV $(25 \%)[15,27,57]$. According to Gandhi et al. [27], significant I:T ratios values for NS are $>0.27$ in term newborns and $>0.22$ in preterm neonates. However, increased values of this marker may also be identified in perinatal asphyxia, maternal hypertension and prolonged labor with oxytocin administration [57]. An association of low WBCs, low ANC and a high of I:T ratio will lead to a greater odds ratio, suggesting NS [18,57]. On the other hand, two normal I:T ratios correlated with a sterile blood culture have maximum NPV $(100 \%)[57]$.

\subsubsection{Hematologic Screening Score (HSS)}

HSS includes WBCs with differential PLT, nucleated red blood cell count, assessment of degenerative and toxic changes in PMN. It is mentioned in two studies that both state that the higher the score, the higher the sensitivity $[18,27]$. A HSS $>3$ in suggestive for NS, but it has the disadvantage of a low PPV $(<31 \%)$ [27]. Even this score needs association with other biomarkers, in order to validate the EOS suspicion $[18,27]$.

\subsection{Acute Phase Reactants}

\subsubsection{C-Reactive Protein (CRP)}

Inflammatory stimuli of any kind, including infection, trauma, or ischemia, generate marginalization, extravasation and activation of the granulocytes and monocytes, resulting in release of pro-inflammatory cytokines such as interleukin-1 $\beta$ (IL-1 $\beta$ ), interleukin-6 (IL-6) and tumor necrosis factor (TNF- $\alpha$ ), which stimulate the production of acute phase reactants. In the adult patients, the reaction times for each of these proteins has been well characterized and it seems that they present similar patterns in neonates. $\mathrm{CRP}$, a cyclic homopentameric protein, is an acute-phase reactant 14 , which binds phosphorylcholine, a component of teichoic acids in Gram-positive organisms, and lipopolysaccharides in Gram-negative organisms, but also lysophosphatidylcholine, ribonucleoproteins, chromatin, and histones from apoptotic cells $[60,61]$. CRP functions as an opsonin for neutrophils and macrophages and activates the classical complement pathway and induces phagocytosis [62]. The serum levels of CRP may increase from 100 to 1000 times in response to bacterial infections or other inflammatory conditions and concentrations correlate with severity of illness [63]. Protein secretion begins primarily in the liver at $4-6 \mathrm{~h}$ after stimulation and reaches the maximum level at 36-48 $\mathrm{h}[16,64,65]$. Once the inflammation trigger is eliminated, CRP concentration decreases rapidly, with a half-life of about $19 \mathrm{~h} \mathrm{[61].} \mathrm{However,} \mathrm{due} \mathrm{to} \mathrm{the} \mathrm{delayed} \mathrm{response,} \mathrm{the} \mathrm{sensitivity} \mathrm{of} \mathrm{CRP} \mathrm{increase} \mathrm{at} \mathrm{the} \mathrm{time} \mathrm{of} \mathrm{evaluation}$ for a clinical suspicion of EOS is low. For a cut-off value of $10 \mathrm{mg} / \mathrm{L}$, the sensitivity for CRP varies between $9-83 \%$, but the majority of studies have reported values of $49-68 \%$ [30]. For the same cut-off value, the specificity was consistently above $90 \%$ [66]. However, in the case of neonatal population, there are multiple other pathological situations, aside from infections (bacterial or viral), associated with an increase in CRP, such as rupture of membranes (which induces an increase in CRP levels by $0.4 \%$ per hour), active labor (14.5\% per hour), maternal administration of steroids $(40 \%)$ or intrapartum antibiotics $(28 \%)$ or chorioamnionitis without invasive fetal or neonatal disease. Moreover, trauma, ischemic tissue injury, hemolysis or meconium aspiration syndrome can result in increased CRP concentrations in the first $24-48 \mathrm{~h}$ of life $[16,63]$. In this context, the value of CRP as a diagnostic marker 
for neonatal EOS is quite low. Even though the accuracy of CRP as a diagnostic marker improves with three serial measurements, its positive predictive value for proven EOS is unacceptably low, of $5 \%$ for a cut-off value of $10 \mathrm{mg} / \mathrm{L}$ and above $10 \%$ only for cut-off values exceeding $50 \mathrm{mg} / \mathrm{L}[24,30,67]$. However, the reported negative predictive value for EOS was $99.7 \%$, which suggests that CRP is more useful for ruling out infection when normal serial values are obtained [16].

\subsubsection{Procalcitonin (PCT)}

PCT is a 116-amino acid precursor peptide of calcitonin without hormonal activity. It is normally produced only by the $C$ cells of the thyroid gland and the circulating concentration is $<0.05 \mathrm{ng} / \mathrm{mL}$ in the serum of healthy subjects. Its levels are not affected by calcitonin levels [57]. In healthy neonates, a physiological increase in the plasma PCT concentration occurs shortly after birth. The peak values are attained at $24 \mathrm{~h}$ of age (mean $1.5-2.5 \mathrm{ng} / \mathrm{mL}$, range $0.1-20 \mathrm{ng} / \mathrm{mL}$ ), followed by a decrease to less than $0.5 \mathrm{ng} / \mathrm{mL}$ by $48-72 \mathrm{~h}$ of life $[68,69]$. In the context of sepsis, PCT is massively produced in the liver and plasma concentrations can increase up to 1000-fold [16]. Levels of $>0.5 \mathrm{ng} / \mathrm{mL}$ suggest systemic infection and possible sepsis and correlate with disease severity [70]. PCT synthesis is stimulated by cytokines such as IL-6, IL-1 $\beta$, and TNF- $\alpha$, or directly by lipopolysaccharides and it is downregulated by interferon- $\gamma$, which is commonly produced in response to viral infections $[16,71,72]$. This might explain why PCT levels are low during viral infections compared with bacterial and fungal infections [70]. PCT concentrations are maximum at 18-24 $\mathrm{h}$ after stimulation and remain elevated for 24-30 h [18,73]. Concentrations decrease rapidly once the inflammation is resolved [70]. However, PCT, similar to CRP, was shown to be increased by several perinatal factors such as prolonged rupture of membranes $\geq 18 \mathrm{~h}$, active labor, maternal administration of steroids or intrapartum antibiotics and also by non-infectious perinatal conditions including intracranial hemorrhage and hypoxic ischemic encephalopathy $[16,18,68,74]$. Mode of delivery appears not to influence PCT concentrations [16]. PCT levels are not affected by sex, but are influenced by birth weight and gestational age [75]. In septic neonates, PCT concentrations reported were increased by $5-20$-fold compared to the measurements obtained in healthy newborns [16]. In an analysis performed by Bell et al. [31], the studies that focused on EOS reported a sensitivity of $0.75(95 \%$ CI, $0.64-0.84)$ and a specificity of $0.83(95 \% \mathrm{CI}, 0.71-0.91)$ for a cut-off value for PCT of $2.5 \mathrm{ng} / \mathrm{mL}$. Establishing the optimal cut-off value of PCT for the diagnosis of EOS is critical, considering the physiologic increase after birth of this marker, which is influenced by both weight and gestational age. Usually, the 95th percentile of normal is typically used as a cut-off point. Eschborn and Weitkamp [16] analyzed three studies that determined the 95th percentile of normal for PCT at different time points during the first $96 \mathrm{~h}$ of life. The data showed that at $0 \mathrm{~h}$ of life (HOL), the cut-off value for both term and preterm was $1 \mathrm{ng} / \mathrm{mL}$ and at $24 \mathrm{HOL}$, the values were $10-20 \mathrm{ng} / \mathrm{mL}$ for term and $50-60 \mathrm{ng} / \mathrm{mL}$ for preterm infants [75-77]. All the presently available data emphasize that the reliability of both CRP and PCT for the diagnosis of EOS requires precise limit values for each assessment time point in the first $48 \mathrm{~h}$ of life $[78,79]$.

\subsubsection{Serum Amyloid A (SAA)}

SAA, an apo-lipoprotein synthesized by the liver, is an acute phase reactant extensively studied in various acute pathologies in adults (cardiac, renal, degenerative disorders) [80-85]. Its levels rise early during the inflammatory response up to 1000 times higher than the baseline serum values but are significantly influenced by the patient's hepatic function and nutritional status. Thus, the value of this molecule is limited in the diagnosis of LOS [28]. However, studies that focused on EOS have shown that SAA had a higher sensitivity, PPV and NPV compared to CRP $(96 \%, 85 \%, 99 \%$ vs. $30 \%, 78 \%$ and $83 \%$, respectively) but a slightly lower specificity ( $95 \%$ vs. $98 \%$ ), with an overall better diagnostic accuracy $[57,86,87]$. 


\subsection{Chemokines and Cytokines}

Acute phase reactants are generated in response to the release of pro-inflammatory cytokines; thus, direct measurement of the serum levels of cytokines seemed to represent earlier clues for infection than the quantification of the secondary responses. Cytokines are divided into pro-inflammatory interferon-gamma (IFN- $\gamma$ ), interleukin-2 (IL-2), interleukin-6 (IL-6), interleukin-8 (IL-8), interleukin-12 (IL-12) and interleukin-17 (IL-17), anti-inflammatory interleukin-4 (IL-4), interleukin-10 (IL-10), tumor necrosis factor soluble receptor (TNF- $\alpha$ ), IL-1 receptor alpha and transforming growth factor beta 2 (TGF- $\beta$ ) and multiple functional inflammatory IL- $1 \beta$, IL-3, monocyte chemoattractant protein (MCP-1) and growth factors (IL-3, G-CSF) [88].

\subsubsection{Interleukin-6 (IL-6)}

Out of all cytokines, IL- 6 is the most studied marker. Its levels rise at $2-4 \mathrm{~h}$ after the onset of infection, right before the clinical signs, symptoms and other diagnostic tests [27]. This interleukin has a good sensitivity of $72-100 \%$, a wide specificity of $47-87.5 \%$, a high NPV between $93-100 \%$ and PPV of $38-100 \%[28,32,58]$. IL- 6 has its own limitations such as a short half-life and a low sensitivity in the case of antibiotic therapy $[18,28,32]$. An advantage is its low value, almost undetectable in healthy newborns when compared with those with sepsis $[34,89]$. Unlike other markers, if there are antenatal risk factors for sepsis (such as chorioamnionitis), IL-6 should be determined in the umbilical cord blood, as its concentration rises significantly in the case of infection $[28,32,90]$. However, the umbilical cord level depends on different factors such as prematurity, maternal usage of steroids and antibiotics given to the mother. The main weakness is that there is no optimal cut-off value to predict EOS $(7-250 \mathrm{pg} / \mathrm{mL})$. The reported values are either from umbilical cord samples or from vein samples at different moments in the first 0-36 h after birth [90]. It is obvious that further studies with standardized methodology are needed to precisely determine IL-6 significant cut-off values for EOS. Another disadvantage is the fact that IL-6 levels rise not only in sepsis but also in hypoxia, fetal distress, preterm birth, usage of antenatal steroids and meconium aspiration syndrome [32]. It was not clear in the study of Chiesa et al. [90] if the levels of IL-6 were influenced by gestational age and the presence of respiratory distress syndrome. In addition, high levels at $24 \mathrm{~h}$ can be associated with the stress of birth, vaginal delivery, active labor, with or without the presence of chorioamnionitis, perinatal asphyxia, fetal acidosis, respiratory distress, low APGAR scores (APGAR is the name of a rapid test used in newborns.) and brain damage [90]. The level of IL- 6 can be used in evaluating the prognosis of sepsis, as the higher the value, the more severe the sepsis [32]. Conversely, Chiesa et al. [90] stated that high levels of IL-6 are not associated with sepsis severity. In order to have a higher sensitivity and a higher NPV, IL-6 has to be associated with other biomarkers, such as CRP and PCT $[15,18,57]$.

\subsubsection{Interleukin-8 (IL-8)}

Interleukin-8 (IL-8) presents a rapid increase (in 1 to $3 \mathrm{~h}$ from stimulation), being an early phase marker in the detection of EOS, but has the disadvantage of a short half-life of only $4 \mathrm{~h}[18$, $27,33,34,57]$. This cytokine has a moderate accuracy, with a sensitivity of $80-91 \%$ and a specificity of $75-100 \%[27,28,33,34,57]$. For a cut-off value of $>60 \mathrm{pg} / \mathrm{mL}$, IL-8 presents a high sensitivity $(95 \%)$ and PPV (97\%) but a low specificity (10\%) and NPV (10\%) [57]. IL-8 does not only correlate with the severity of infection, but is also appears to be more efficient in diagnosing EOS prior to other markers (IL-6, IL-10) $[28,30,32,34,57]$. However, Sharma et al. concluded that IL- 8 alone is not useful in the diagnosis and prognosis of sepsis, probably because its concentration rises also in necrotizing enterocolitis (NEC), surgery, trauma and meconium aspiration syndrome [10,33]. If associated with CRP, the sensitivity and specificity of IL-8 increase $[18,33,57]$. 


\subsubsection{Interleukin-10 (IL-10)}

Even if IL-10 is not frequently studied as it is less expressed in neonates, an increased value is very suggestive for a severe infection, usually associated with multi organ damage $[30,33,34]$. It can predict the prognosis and survival of a neonate affected by sepsis [33]. While in other studies, IL-8 is known to be the most useful marker in the diagnosis of EOS, Memar et al. [34] stated that IL-10 is the best with a sensitivity and a specificity of $92 \%$ and $84 \%$, respectively, for a cutoff value of $\geq 173 \mathrm{pg} / \mathrm{mL}$. The value of IL-10 can also increase in the same situations as IL-6 and IL-8 [10]. High values of IL-10 (cut-off $>208 \mathrm{ng} / \mathrm{L}$ ) in association with high values of IL-6 (cut-off $>168 \mathrm{ng} / \mathrm{L}$ ) are suggestive for disseminated intravascular coagulation (DIC) in neonates with sepsis. This combination of markers leads to a sensitivity of $100 \%$, specificity of $97 \%$, PPV of $85 \%$ and NPV of $100 \%$. It is important to note that cut-off values differ in measurement units, which imposes more studies to precisely decide the accurate value $[18,30]$.

\subsubsection{Interleukin-35 (IL-35)}

Interleukin-35 (IL-35) is a newly described cytokine from the family of IL-12. It contributes to the regulation of host immunity by suppressing T-helper (Th) 1, Th 2 and Th 17 cell responses. Its levels are increased in systemic sclerosis, allergic rhinitis, and septic shock in adults. In neonates with EOS, IL-35 has not only the advantage of increasing rapidly ( $6 \mathrm{~h}$ after infection, with a peak at $12 \mathrm{~h}$ ) but also of remaining stable for up to 3 days [34,91]. In addition, it can be useful for the prognosis of EOS. For a cut-off value of $317 \mathrm{ng} / \mathrm{mL}$, this interleukin showed a sensitivity of $78.48 \%$ and a specificity of $66.67 \%$ [34].

\subsubsection{Tumor Necrosis Factor (TNF- $\alpha$ )}

TNF- $\alpha$ concentration increases fast in 2 to $4 \mathrm{~h}$ in both infection and inflammation, having a sensitivity of $75 \%$, specificity of $88 \%$, PPV of $67 \%$ and NPV of $51 \%$ for $130 \mathrm{ng} / \mathrm{mL}$ as the cut-off value [30]. Hence, on its own, it is not a useful marker for the diagnosis of EOS, having a moderate accuracy (sensitivity of $66-78 \%$ and a specificity of $41.2-76 \%$ ) [34,57]. However, in combination with IL-6, its sensitivity rises to $60 \%$ and its specificity increases to $100 \%$ [57]. On one hand, the sensitivity is higher at birth and decreases with the postnatal age (lower at $24 \mathrm{~h}$ ); on the other hand, the NPV is more accurate at $24 \mathrm{~h}$ than at birth (73-86\%) [88]. The main strength of this marker is that its level is not influenced by the gestational or postnatal age [57]. Recently, controversies were raised by Sharma et al., who stated that TNF- $\alpha$ has no value in the prognosis of sepsis [33].

\subsection{Presepsin (sCD14-ST)}

Presepsin, a cleaved truncated form of soluble CD14 (sCD14), is a surface glycoprotein with a high affinity for lipopolysaccharides, and according to recent studies, it may be a better marker than CRP and PCT for the diagnosis of EOS [92]. sCD14 level not only increases in the first $24 \mathrm{~h}$ after the onset of infection, just before CRP and PCT, but also has a higher area under the curve (AUC, 0.97-0.99), being considered an efficient marker in diagnosing EOS [33,91,93,94]. In a newborn without signs of infection, the mean value of presepsin differs in term $(649 \mathrm{ng} / \mathrm{L})$ compared to premature infants $(720 \mathrm{ng} / \mathrm{L})$ [95]. In contrast, in the case of infection, its value does not vary with GA, postnatal age or with other perinatal factors [92]. The current data also suggest that the value decreases progressively with the administration of antibiotics, and thus having the advantage of monitoring the response to therapy $[91,94]$. In order to establish a suggestive cut-off value for EOS, further studies are needed. Cut-off values, sensitivity and specificity differ within EOS from LOS. In EOS, the cut-off varies between 305 and $672 \mathrm{ng} / \mathrm{L}$ and has a sensitivity of $81 \%$ and a specificity of $86 \%$. Ruan et al. [91] suggested higher values of sensitivity and specificity at a cut-off value of $722 \mathrm{ng} / \mathrm{L}$, but the authors do not specify whether they occur in the case of EOS or LOS. A higher value of $788 \mathrm{ng} / \mathrm{L}$ has a sensitivity of $93 \%$ and a specificity of $100 \%$ [95]. Additionally, a value of $539 \mathrm{ng} / \mathrm{L}$ demonstrated a sensitivity 
of $80 \%$, a lower specificity of $75 \%$, a PPV of $91 \%$ and NPV of $59 \%$. Elevated levels of presepsin are significantly associated with mortality at 30 days [94]. sCD14-ST is efficient in diagnosing bacterial sepsis, especially if Gram-negative bacteria are present [30,34]. The main bias is that the type of measurements differs between various studies, leading to a larger range in the significance of cut-off values. Parri et al. [96] included in a study a large number of neonates and concluded that presepsin has a high accuracy in diagnosing EOS with a sensitivity and specificity of around $90 \%$.

\subsection{Novel Biomarkers Currently under Investigation}

\subsubsection{Endocan}

The vascular endothelium is a component of the innate defense system with an important role in early recognition and limitation of bacterial invasion and a dynamic participant in cellular and organic processes. It controls vascular tone and permeability by expression of surface proteins and secretion of soluble mediators, regulates coagulation and thrombosis and coordinates recruitment and direction of leucocytes towards inflammation sites, with the involvement of surface molecules such as E- and P-selectins, intercellular adhesion molecule 1 and vascular cell adhesion molecule 1 , whose expression is regulated by pro-inflammatory cytokines such as TNF- $\alpha$ and IFN- $\gamma[97,98]$. However, excessive endothelial activation may lead to systemic overproduction of cytokines and vasoactive substances associated with circulation disturbances and organ dysfunction in severe sepsis and septic shock [99]. Endocan (formerly known as endothelial cell specific molecule-1 or ESM-1) is one of the specific endothelial mediators with a structure of chondroitin/dermatan sulfate glycosaminoglycan and a molecular weight of approximately $50 \mathrm{kDa}$ [100]. Normally, endocan is localized mainly within the vascular endothelium, the distal tubules of the kidneys and in the lungs, at the level of small veins, arterioles, alveolar capillaries, bronchial epithelial cells and submucosal glands [101]. In healthy subjects, the serum concentration of endocan is low, but the levels are significantly increased in patients with sepsis and are correlated with disease severity [98,102-106]. Moreover, in newborns without infection, during the first $72 \mathrm{~h}$ of life, endocan serum level does not appear to be significantly influenced by sex, delivery method, the presence of meconium in the amniotic fluid, fetal bradycardia/tachycardia or presence of minor birth trauma (ecchymosis, cephalohematoma, clavicle fracture), which have been associated with elevation of CRP and PCT [107]. For EOS at a cut-off value of $1.62 \mathrm{ng} / \mathrm{mL}$, the reported sensitivity of serum endocan was $88 \%$ and the specificity was $50 \%$. At a higher threshold value of $>2.15 \mathrm{ng} / \mathrm{mL}$, specificity improved to $81 \%$, but the sensitivity decreased to $52 \%$ [106]. This suggests that currently the clinical utility of endocan as a single marker for the diagnosis of neonatal EOS is limited. However, serum endocan could prove useful in combination with inflammatory markers as a part of a diagnostic tool for EOS, or if used at a low threshold, for ruling out sepsis, but more studies are necessary to establish the clinical utility of this molecule as a marker for diagnosis of EOS.

\subsubsection{Cluster of Differentiation 64 (CD64)}

CD64 is a high affinity FC receptor for immunoglobulin G and is expressed by inflammatory cells in response to bacterial infection $[27,33,34,88]$. Its value increases 5 to 10 times in the presence of sepsis, at an interval of 1-6 h of onset and remains stable over a period of $24 \mathrm{~h}[30,33]$. Its advantages include rapid detection by flow-cytometry, the need for a small amount of blood and the results being available in a maximum of $4 \mathrm{~h}[15,18,34,108]$. In addition, the value of CD64 is not influenced by transient tachypnea of the newborn (TTN), respiratory distress syndrome or other non-infectious factors commonly occurring during the first $72 \mathrm{~h}$ of life [108]. Its value returns to normal in a few days after the immune system removes the infection, but a study has suggested that the peak of this marker would be at $48 \mathrm{~h}[30,33]$. Repeated dosing is required to guide antibiotic therapy [18]. For a cut-off between $2.19-3.62$, CD64 has a sensitivity of 75-78\%, specificity of 59-77\%, PPV $29-54 \%$ and NPV 81-96\% [33]. CD64 is able to detect systemic infection 1.5 days before the onset of symptoms due to high sensitivity (89\%), specificity (98\%) and PPV (99\%) [59]. Given that on its own it has a 
moderate accuracy in diagnosing EOS, over the years various combinations with other biomarkers have been tried to increase its diagnostic value. In combination with elevated CRP and interleukin values or CD11b, the sensitivity and NPV of CD64 reach maximum value $[18,28,33,34]$. Weaknesses of this biomarker include high cost, lack of growth in viral infections, the presence of a moderately high value in premature infants that becomes similar to normal values in term newborns only after one month of life and high values not only in neonatal sepsis but also in NEC or other digestive pathology $[15,18,30]$. In adults, the value of CD64 is higher in infections with Gram-negative bacteria than in those due to Gram-positive organisms, which has not been demonstrated in the newborn [108]. In conclusion, CD64 has limited utility on its own; therefore, most authors recommend associating it with other markers, clinical signs or even with hematological scoring systems [18,30,108].

\subsubsection{Cluster of Differentiation Molecule 11b (CD11b)}

Neutrophil CD11b can be detected rapidly by flow cytometry, being considered an early marker of NS $[27,109]$. Its value increases within 5 min of bacterial exposure, making it a more accurate marker in the diagnosis of EOS (92\% sensitivity, $99 \%$ specificity) $[11,30,57,109]$. In addition, due to the high surface density of neutrophils and monocytes, neutrophil CD11b may be a useful marker in diagnosing EOS even in VLBW [30]. Although it has very good qualities for EOS detection, the lack of detection methods in clinical settings and the cost-effectiveness ratio makes this marker suitable only for research purposes (for now) [57]. In a study by Stalhammar et al. [110], upregulation of neutrophil CD11b after stimulation with formyl-methionyl-leucyl-phenylalanine (fMLP), generated by organisms such as Escherichia coli and Staphylococcus aureus, revealed alterations in receptor expression that were of the same strength in neutrophils from neonates as from adults. Moreover, the results of the research presented similar expression of receptors that mediate adhesion, migration, granule activation and phagocytosis determined by fMLP in neutrophils. CD15s, a selectin ligand involved in the inflammation process, appears to be a useful marker in differentiating viral from bacterial infection. A study by Markic et al. [111] proposed a model for identifying serious bacterial infection in pediatric patients under 6 months and found that the correlation between percentage of neutrophils expressing CD15s $\left(\% \mathrm{CD}_{15 S^{+}}\right), \mathrm{CRP}$ and PCT presented a sensitivity of $87 \%$ and a specificity of 83\%. E-selectin (CD62) and L-selectin (CD62L) are selectins activated by acute inflammation [30]. Stoll et al. [17] showed that for CD62 at $161.7 \mathrm{mg} / \mathrm{L}$, there was sensitivity of $50 \%$ and specificity of $93.9 \%$ for the diagnosis of EOS. In addition, no correlation was observed between the levels of CD62L and infants with bacterial infection [30]. Elevated levels of sCD13 (macrophage cell surface glycoprotein receptor) are significantly associated with neonatal infection before the use of antibiotics. For a cut-off value of $>896.78 \mathrm{ng} / \mathrm{mL}$, the reported sensitivity was $100 \%$ and the specificity was $88 \%$ [57].

\subsubsection{Pancreatic Stone Protein (PSP)}

PSP, a $16 \mathrm{kDa}$ C-type lectin protein, is secreted by the pancreas in response to systemic stress and organ damage associated with sepsis. Observations that PSP levels rise in mice and rats in response to septic insults have led to studies based on adults that demonstrated its role as a potential biomarker in sepsis, and sepsis associated with multiple-organ failure in patients with ventilator-acquired pneumonia or post-traumatic sepsis [112]. El Meneza et al. [113] published a case control study on 90 newborn infants demonstrating that PSP was significantly higher in EOS compared to normal newborns, with $100 \%$ sensitivity and sensibility, PPV and NPV at a cut-off point $>133.8 \mathrm{pg} / \mathrm{mL}$, and a cut-off value of $125.6 \mathrm{pg} / \mathrm{mL}$ for preterm infants, also suggesting a useful value in EOS prognosis (as a statistically significant increase in PSP was observed among non-survival cases) [113]. Similar data were reported by Rass et al. [114] in a hospital-based prospective study conducted on 104 newborn infants, who found a cut-off level of $12.96 \mathrm{ng} / \mathrm{mL}$, with good sensibility (96.2\%), specificity (88.5\%), PPV (95.8\%) and NPV (89.3\%). Additionally, Schlapbach et al. reported that PSP had a superior accuracy for EOS diagnosis compared to other markers such as CRP and PCT, and provided fast results with a very small amount of blood required for sampling [115]. The increase in PSP in septic newborns was explained 
by promoting proliferative responses in pancreatic cells and activation of polymorph nuclear cells, $\mathrm{PSP} / \mathrm{reg}$ binds, activating neutrophils and behaving as acute phase reacting protein to early phase injury of infection. The statistically higher levels of PSP in non-surviving infants with EOS support a role for this biomarker in prediction of illness severity and unfavorable outcome [113].

Recently, nanofluidic technology was employed to develop a rapid PSP test for EOS, requiring only a few drops of blood and results available within minutes, with a very good precision of about $90 \%[112,116]$.

\subsubsection{Soluble Intercellular Adhesion Molecule 1 (sICAM-1)}

Soluble intercellular adhesion molecule 1 (sICAM-1) is a protein factor used in the transfer of neutrophils to the site of inflammation in vivo [117]. During infection, after activation of endothelial cells by cytokines, a rapid rise (within 1-6 h) in the serum sICAM-1 levels is noticed [118]. Neonatal sepsis is associated with increased serum sICAM-1 concentrations, which are correlated with severity of disease. The higher the serum value of sICAM-1, the more severe the infection [30]. Zhang et al. reported mean sensitivity and specificity of $76.9 \%$ and $82 \%$, respectively, but infants with EOS and LOS were evaluated together, without differentiating the two entities [117]. Currently there is controversy regarding the usefulness of this marker in diagnosing EOS, as some authors proposed sICAM-1 as a valuable marker only in the first 4 days of life [119] and others have noticed similar or even higher levels in healthy newborns in the first 5 days [120]. Moreover, the proposed cut-off values vary significantly between studies and the accuracy as a diagnostic marker is questionable. For EOS, a cut-off of $228 \mathrm{ng} / \mathrm{mL}$ had a reported sensitivity of $33.3 \%$, and specificity of $95 \%$, with PPV of $50.3 \%$ and NPV of $90.35 \%$ [121], meanwhile a cut-off value of $400 \mathrm{ng} / \mathrm{mL}$ had a better sensitivity $(64 \%)$ and similar NPV $(90 \%)$, but a lower specificity (68\%) and PPV (30\%) [30]. The diagnostic value of sICAM-1 can be significantly improved if used in association with PCT, presenting an AUC of 0.81 , as shown by Zhang et al. [117]. Considering the controversial data reported for this biomarker, further studies are required to assess its potential utility in EOS diagnosis.

\subsubsection{Serum Leptin}

Serum leptin, an immune regulatory hormone that enhances immune response with macrophage effector function, was found to have a higher level in neonates with positive blood cultures compared to those with negative blood cultures, but there was no difference between survivors and non survivors [122]. For a cut-off value of $2.75 \mathrm{ng} / \mathrm{mL}$, the sensitivity and specificity were $75 \%$ and $70 \%$, respectively.

\subsubsection{Progranulin}

Progranulin, a 593-amino-acid autocrine growth factor that regulates the tumor necrosis factor/tumor necrosis factor receptor (TNF/TNFR) signaling system, was recently studied also in neonates and may significantly predict EOS in neonates $>34$ weeks of gestation, with a cut-off value of $37.89 \mathrm{ng} / \mathrm{mL}$, at which the sensitivity and negative predictive value was $94.34 \%$ and $91.7 \%$, respectively. When combined with PCT, the diagnostic performance was improved to a specificity of $89.06 \%$ and positive predictive value of $81.1 \%$ [123].

\subsubsection{Neopterin}

Neopterin is a biochemical marker for immune activity. Increased serum concentrations can be detected in situations when there is cell-mediated immune response. Data from small study groups suggest a better correlation with severity and mortality from sepsis compared to CRP. For a cut-off value of $70.56 \mathrm{nmol} / \mathrm{L}$, this marker has a specificity of $88.6 \%$ and a sensitivity of $94.7 \%$ to detect sepsis. However, the reported results are not specific to EOS [124]. 


\subsubsection{Resistin}

Resistin, also known as adipocyte-specific secretory factor or FIZZ3, is a protein rich in cysteine with a controversial physiological role in obesity and insulin resistance. Some studies on adult and neonatal patients have reported elevated serum levels during inflammation and infection. The few studies conducted on newborns have suggested that this marker could be an indicator of EOS, but its diagnostic value proved to be less than that of CRP and the cut-off value could not be established with accuracy due to several factors such as control group and number of days since the first sign of sepsis $[125,126]$. Some biomarkers such as sTREM-1 (human triggering receptor expressed on myeloid cells-1), pentraxin-3 and pro-adrenomedullin, which were found to have high values in infected adults and children, failed to prove their role in neonatal EOS [127].

\subsection{Molecular Techniques}

Molecular diagnostics have the potential of providing results in less than $12 \mathrm{~h}$ with better sensitivity than blood cultures $[11,58]$. These techniques evaluate gene expression in disease and would be most useful for neonates with EOS born to mothers who have received intrapartum treatment with antibiotics. The $16 \mathrm{~S}$ rRNA (ribonucleic acid) and 18S rRNA genes are preserved in all bacteria and in all candida species, respectively. Using the microarray hybridization technique, polymerase chain reaction (PCR) can detect the presence of bacteremia and also identify the infecting organism [128]. According to a meta-analysis that include 23 studies on PCR-based molecular methods, mean sensitivity and specificity of PCR for the bacterial 16S rRNA gene for the diagnosis of EOS were $0.90(95 \% \mathrm{CI}$, 0.78 to 0.95 ) and 0.96 (95\% CI, 0.94 to 0.97$)$, respectively [15,47]. The sensitivity of the assay depends on the accuracy of the extraction process and the presence of inhibitors and can be improved by pre-incubation of samples before PCR processing [58]. Compared to blood culture, PCR has the advantages of higher accuracy, a significantly shorter time to result (4-6 h) and a much less amount of required blood for sample $(0.2-0.3 \mathrm{~mL})$. However, the main disadvantage is its high cost and reduced availability [128]. Molecular diagnostic techniques represent a promising perspective, but more studies are needed to assess their clinical utility, as there is still uncertainty about whether the detected bacteria actually represent the cause for the sepsis-like symptoms in a specific patient [58]. Taking into account the current data available, molecular assays are not sensitive enough to completely replace microbial cultures in the diagnosis of EOS, but are useful as adjunctive tests [15]. Blood cultures remain the gold standard for the detection of bacteremia or fungemia, despite their low sensitivity and prolonged time required for results (48 to $72 \mathrm{~h}$ ) [11].

\section{Concluding Remarks}

Despite the abundance of data already published regarding biomarker identification for EOS, there is no consensus yet concerning a diagnostic protocol, as many factors may affect the interpretation of the values of each marker. For an easier uptake of the extensive information on laboratory assays currently used for EOS diagnosis, in Table 3 we emphasized some "pros" and "cons" of the above discussed biomarkers.

Based on latest data summarized in the present study, we intend to propose a short panel for clinical use that could guide the recommendations for assays in neonates with suspicion of EOS, depending on the available financial resources (Table 4).

According to the results discussed in this review, detection and currently available validity of an EOS clinical diagnosis are still unsatisfactory and we emphasize the need for further improvement of clinical criteria for EOS using modern biomarkers. The present study underlines the relevance of biomarkers in the search for a rapid, more precise, and effective diagnosis in EOS individuals for minimizing errors and their possible sequelae. Testing modalities for the detection and diagnosis of EOS continue to be developed, with novel laboratory methods still being tested. Sustained vigilance will be crucial in the diagnosis and neonatal sepsis management. 
Table 3. Synopsis of the main characteristics of the discussed biomarkers for EOS diagnosis.

\begin{tabular}{|c|c|c|}
\hline MARKER & PROS & CONS \\
\hline Blood culture & $\begin{array}{c}\text { Gold standard for diagnosis } \\
\text { High sensitivity (95\%) and specificity } \\
(99 \%)\end{array}$ & $\begin{array}{l}\text { Low bacteremia detected only in larger } \\
\text { samples }(>1 \mathrm{~mL}) \\
\text { Results available in up to } 72 \mathrm{~h} \\
\text { Possible false negative results with prior } \\
\text { antepartum or empirical antibiotic } \\
\text { therapy administered } \\
\text { Not useful in viral sepsis. }\end{array}$ \\
\hline Cerebrospinal Fluid & $\begin{array}{l}\text { The only assay available to confirm } \\
\text { neonatal meningitis }\end{array}$ & $\begin{array}{l}\text { Difficulties in interpretation of the results } \\
\text { Risky procedure } \\
\text { Possible false negative results with prior } \\
\text { antepartum or empirical antibiotic } \\
\text { therapy administered. }\end{array}$ \\
\hline White Blood Cells & $\begin{array}{c}\text { Universally available } \\
\text { Included in the initial complete blood } \\
\text { count workup } \\
\text { High specificity }(91 \%) \text { for leucopenia } \\
<5000 / \mathrm{mm}^{3} \\
\text { Low cost }\end{array}$ & $\begin{array}{l}\text { Low sensitivity (29\%) even for leucopenia } \\
<5000 / \mathrm{mm}^{3} \\
\text { Late increase of WBCs after sepsis onset; } \\
\text { Low PPV and NPV }\end{array}$ \\
\hline $\begin{array}{l}\text { Platelet (PLT) and } \\
\text { mean platelet volume } \\
\text { (MPV) }\end{array}$ & $\begin{array}{l}\text { Universally available; } \\
\text { Included in the initial complete blood } \\
\text { count workup; } \\
\text { Low cost. }\end{array}$ & $\begin{array}{l}\text { Low sensitivity and specificity for EOS } \\
\text { Only a suggestive role in the diagnosis } \\
\text { of EOS }\end{array}$ \\
\hline $\begin{array}{l}\text { Absolute Neutrophil } \\
\text { Count }\end{array}$ & $\begin{array}{l}\text { Included in the initial complete blood } \\
\text { count workup }\end{array}$ & $\begin{array}{c}\text { Large variability depending on different } \\
\text { associated pathologies } \\
\text { Practical significance after } 6-12 \mathrm{~h} \\
\text { form onset } \\
\text { Delays treatment }\end{array}$ \\
\hline $\begin{array}{l}\text { Immature to Total } \\
\text { Neutrophil Ratio (I:T } \\
\text { ratio) }\end{array}$ & $\begin{array}{l}\text { Included in the initial complete blood } \\
\text { count workup } \\
\text { Easy assessment High sensitivity } \\
(90 \%) \\
\text { High NPV }(98-99 \%) \\
2 \text { serial normal values increase NPV } \\
\text { up to } 100 \% \text { if associated with negative } \\
\text { blood culture }\end{array}$ & $\begin{array}{c}\text { Low PPV }(25 \%) \\
\text { High values also in other specific neonatal } \\
\text { conditions }\end{array}$ \\
\hline $\begin{array}{l}\text { C-Reactive Protein } \\
\text { (CRP) }\end{array}$ & $\begin{array}{l}\text { Marked increase of serum levels in } \\
\text { response to inflammatory conditions } \\
\text { Concentrations correlate with severity } \\
\text { of illness } \\
\text { Specificity }>90 \% \\
\text { Low cost Extensive availability } \\
\text { High NPV with normal values useful } \\
\text { to rule out sepsis }\end{array}$ & $\begin{array}{l}\text { Maximum level reached at } 36-48 \mathrm{~h} \\
\text { Very large variation in reported sensitivity } \\
\text { Increased in multiple other pathological } \\
\text { situations, aside from infections }\end{array}$ \\
\hline Procalcitonin & $\begin{array}{c}\text { Rapid increase, maximum levels at } \\
\text { 18-24 h after stimulation and remain } \\
\text { elevated for } 24-30 \mathrm{~h} \\
\text { Correlates with EOS severity } \\
\text { High availability Affordable cost }\end{array}$ & $\begin{array}{l}\text { Physiologic increase after birth } \\
\text { Not useful in viral infections } \\
\text { Increased by several non-infectious } \\
\text { perinatal factors Levels influenced by } \\
\text { birth weight and gestational age } \\
\text { No optimal cut-off value }\end{array}$ \\
\hline Serum Amyloid A & $\begin{array}{c}\text { Early rise of concentration } \\
\text { High sensitivity, specificity and NPV }\end{array}$ & $\begin{array}{c}\text { Influenced by the patient's hepatic } \\
\text { function and nutritional status } \\
\text { Not commonly available in } \\
\text { clinical settings }\end{array}$ \\
\hline
\end{tabular}


Table 3. Cont.

\begin{tabular}{|c|c|c|}
\hline MARKER & PROS & CONS \\
\hline Presepsin & $\begin{array}{l}\text { Increases in the first } 24 \mathrm{~h} \\
\text { Not influenced by GA, postnatal age } \\
\text { or by other perinatal factors } \\
\text { Monitoring the response to therapy } \\
\text { High accuracy }\end{array}$ & $\begin{array}{l}\text { Different cutoff values for term and } \\
\text { preterm neonates } \\
\text { No optimal cut-off value for EOS } \\
\text { Relative high cost Not commonly } \\
\text { available in clinical settings }\end{array}$ \\
\hline Interleukin-6 & $\begin{array}{l}\text { Rise at } 2-4 \mathrm{~h} \\
\text { Low value in healthy newborns } \\
\text { Correlates with EOS severity }\end{array}$ & $\begin{array}{c}\text { Wide range for specificity and PPV } \\
\text { Short half-life Low sensitivity in case of } \\
\text { antibiotic therapy } \\
\text { No optimal cut-off values } \\
\text { Rise in other non-infectious conditions } \\
\text { Needs association with other markers } \\
\text { Not commonly available in } \\
\text { clinical settings }\end{array}$ \\
\hline Interleukin-8 & $\begin{array}{l}\text { Rapid increase }(1 \text { to } 3 \mathrm{~h}) \\
\text { Correlates with the severity of } \\
\text { infection }\end{array}$ & $\begin{array}{c}\text { Short half-life }(4 \mathrm{~h}) \\
\text { Moderate accuracy Rise in other } \\
\text { non-infectious conditions } \\
\text { Needs association with other markers } \\
\text { Not commonly available in } \\
\text { clinical settings }\end{array}$ \\
\hline Interleukin-10 & $\begin{array}{c}\text { Suggestive for a severe infection } \\
\text { associated with multi organ damage } \\
\text { Can predict the prognosis } \\
\text { and survival }\end{array}$ & $\begin{array}{c}\text { Less expressed in neonates } \\
\text { Rise in other non-infectious conditions } \\
\text { Not commonly available in } \\
\text { clinical settings }\end{array}$ \\
\hline Interleukin-35 & $\begin{array}{c}\text { Rapid increase }(6 \mathrm{~h}) \\
\text { Peak at } 12 \mathrm{~h} \\
\text { Remains stable up to } 3 \text { days } \\
\text { Useful for the prognosis of EOS }\end{array}$ & $\begin{array}{l}\text { Moderate accuracy } \\
\text { Not commonly available in } \\
\text { clinical settings }\end{array}$ \\
\hline Tumor Necrosis Factor & $\begin{array}{l}\text { Rapid increase ( } 2 \text { to } 4 \mathrm{~h} \text { ) } \\
\text { Not influenced by age }\end{array}$ & $\begin{array}{c}\text { Moderate accuracy } \\
\text { Not commonly available in } \\
\text { clinical settings }\end{array}$ \\
\hline Endocan & $\begin{array}{l}\text { Correlates with disease severity } \\
\text { Low in healthy newborns Levels not } \\
\text { influenced by sex, delivery method or } \\
\text { other non-infectious perinatal factors }\end{array}$ & $\begin{array}{c}\text { Needs correlation with other markers } \\
\text { Moderate accuracy } \\
\text { Not commonly available in } \\
\text { clinical settings }\end{array}$ \\
\hline $\begin{array}{l}\text { Cluster of } \\
\text { Differentiation } 64 \\
\quad(C D 64)\end{array}$ & $\begin{array}{l}\text { Rapid increase }(1-6 \mathrm{~h}) \\
\text { Remains stable up to } 24 \mathrm{~h} \\
\text { Rapid detection by flow-cytometry } \\
\text { Need for a small amount of blood } \\
\text { Results available in maximum } 4 \mathrm{~h}\end{array}$ & $\begin{array}{c}\text { Peak at } 48 \mathrm{~h} \text { Repeated dosing required to } \\
\text { guide antibiotic therapy } \\
\text { Moderate accuracy } \\
\text { Needs correlation with other markers } \\
\text { High cost } \\
\text { Lack of growth in viral infections } \\
\text { High values not only in neonatal sepsis } \\
\text { but also in necrotizing enterocolitis (NEC) } \\
\text { or other digestive pathology }\end{array}$ \\
\hline $\begin{array}{c}\text { Cluster of } \\
\text { Differentiation } \\
\text { Molecule 11b (CD 11b) }\end{array}$ & $\begin{array}{l}\text { Rapid detection by flow-cytometry } \\
\text { Early marker (increases within } 5 \text { min } \\
\text { of bacterial exposure) } \\
\text { High sensitivity and specificity }\end{array}$ & $\begin{array}{l}\text { Not commonly available in } \\
\text { clinical settings } \\
\text { Unfavorable cost-effectiveness ratio }\end{array}$ \\
\hline Serum Leptin & $\begin{array}{c}\text { Higher level in neonates with positive } \\
\text { blood cultures compared to those with } \\
\text { negative blood cultures }\end{array}$ & $\begin{array}{c}\text { No difference between survivors and non } \\
\text { survivors Moderate accuracy } \\
\text { Not commonly available in } \\
\text { clinical settings }\end{array}$ \\
\hline
\end{tabular}


Table 3. Cont.

\begin{tabular}{|c|c|c|}
\hline MARKER & PROS & CONS \\
\hline Progranulin & High sensitivity and NPV & $\begin{array}{c}\text { May significantly predict EOS only in } \\
\text { neonates }>34 \text { gestational age (GA) } \\
\text { Not commonly available in } \\
\text { clinical settings }\end{array}$ \\
\hline Neopterin & $\begin{array}{l}\text { Better correlation with severity and } \\
\text { mortality compared to CRP }\end{array}$ & $\begin{array}{l}\text { Results not specific to EOS } \\
\text { Not commonly available in } \\
\text { clinical settings }\end{array}$ \\
\hline Resistin & $\begin{array}{l}\text { Elevated serum levels during } \\
\text { inflammation and infection }\end{array}$ & $\begin{array}{l}\text { Few studies conducted on newborns } \\
\text { Cut-off value could not be established } \\
\text { with accuracy } \\
\text { Not commonly available in } \\
\text { clinical settings }\end{array}$ \\
\hline $\begin{array}{l}\text { Soluble Intercellular } \\
\text { Adhesion Molecule } 1 \\
\text { (sICAM-1) }\end{array}$ & $\begin{array}{l}\text { Rapid rise (within } 1-6 \mathrm{~h} \text { ) } \\
\text { Correlated with severity of disease }\end{array}$ & $\begin{array}{c}\text { Moderate sensitivity and specificity } \\
\text { Controversial value for EOS diagnosis } \\
\text { Proposed cut-off values vary significantly } \\
\text { Questionable accuracy } \\
\text { Not commonly available in } \\
\text { clinical settings }\end{array}$ \\
\hline $\begin{array}{l}\text { Pancreatic Stone } \\
\text { Protein (PSP) }\end{array}$ & $\begin{array}{l}\text { High accuracy } \\
\text { Fast results Very small amount of } \\
\text { blood required for sampling } \\
\text { Prediction of illness severity and } \\
\text { unfavorable outcome }\end{array}$ & $\begin{array}{l}\text { Not commonly available in } \\
\text { clinical settings }\end{array}$ \\
\hline
\end{tabular}

Table 4. Potential panel for EOS evaluation.

\begin{tabular}{|c|c|c|c|}
\hline Assay & Sensitivity & Specificity & Average Cost per Assay \\
\hline Blood count with differential [29] & 59.5 & 79.6 & $€ 6.68-23.1 *[129,130]$ \\
\hline Culture (blood, CSF) [128] & 36 & 92 & $€ 175^{* *}[131]$ \\
\hline $\mathrm{CRP}^{\mathrm{b}}[30]$ & 49 & 91 & $€ 11.27[132]$ \\
\hline $\mathrm{PCT}^{\mathrm{c}}[69]$ & 75 & 83 & $€ 31.71[133]$ \\
\hline IL-6 [34] & 79 & 84 & $€ 18.20-44.23[134,135]$ \\
\hline Presepsin d [95] & 93 & 100 & $€ 7.5-38.10[133,136]$ \\
\hline PCR (16S rRNA) [47] & 90 & 96 & $€ 121.75-353.90[137]$ \\
\hline Endocan ${ }^{\mathrm{e}}[106]$ & 88 & 50 & $\mathrm{NA}^{* * *}$ \\
\hline
\end{tabular}

CRP, C-reactive protein; PCT, procalcitonin; IL-6, interleukin-6; PCR, polymerase chain reaction; RNA, ribonucleic acid; CSF, cerebrospinal fluid. ${ }^{\mathrm{b}}$ cut-off value $>10 \mathrm{mg} / \mathrm{L} ;{ }^{c}$ cut-off value $>2.5 \mathrm{ng} / \mathrm{mL} ;{ }^{d}$ cut-off value $>788 \mathrm{ng} / \mathrm{L}$; ${ }^{\mathrm{e}}$ cut-off value $>1.62 \mathrm{ng} / \mathrm{mL}$; ${ }^{*}$ GBP 1 = EUR $1.1 ;{ }^{* *}$ USD 147.5 for microbiology plus USD 60.5 for identification (USD 1 = EUR 0.84 ); ${ }^{* * *}$ currently not available for commercial distribution.

Author Contributions: Conceptualization, L.P. and G.-I.Z.; methodology, L.P., G.-I.Z. and M.-A.H.; validation, L.P., G.-I.Z., M.-A.H., G.D.S. and D.N.; formal analysis, M.-A.H.; writing-original draft preparation, L.P., G.-I.Z. and M.-A.H.; writing-review and editing, L.P., G.-I.Z., M.-A.H. and G.D.S. supervision, L.P. and D.N. All authors have read and agreed to the published version of the manuscript.

Funding: This research received no external funding.

Conflicts of Interest: The authors declare no conflict of interest. 


\section{Abbreviations}

\begin{tabular}{ll} 
ANC & absolute neutrophil count \\
CD11b & cluster of differentiation molecule 11b \\
CD64 & cluster of differentiation 64 \\
cfu & colony-forming unit \\
CRP & C-reactive protein \\
CSF & cerebrospinal fluid \\
ELBW & extremely low birth weight \\
EOS & early-onset sepsis \\
fMLP & formyl-methionyl-leucyl-phenylalanine \\
GA & gestational ages \\
HOL & hours of life \\
HPeV & human parechovirus \\
HSS & Hematologic Screening Score \\
HSV & herpes simplex virus \\
I:T ratio & immature to total neutrophil ratio \\
IFN- $\gamma$ & pro-inflammatory interferon-gamma \\
IL-12 & interleukin-12 \\
IL-1 $\beta$ & interleukin-1 $\beta$ \\
IL-2 & interleukin-2 \\
IL-4 & anti-inflammatory interleukin-4 \\
IL-6 & interleukin-6 \\
LOS & late-onset sepsis \\
LP & lumbar puncture \\
MCP-1 & monocyte chemoattractant protein-1 \\
MPV & mean platelet volume \\
NS & neonatal sepsis \\
PCR & polymerase chain reaction \\
PCT & procalcitonin \\
PLT & platelet \\
PSP & pancreatic stone protein \\
SAA & serum amyloid A \\
sICAM-1 & soluble intercellular adhesion molecule 1 (sICAM-1) \\
sTREM-1 & human triggering receptor expressed on myeloid cells-1 \\
TGF- $\beta$ & transforming growth factor beta \\
TNF- $\alpha$ & tumor necrosis factor \\
TTN & transient tachypnea of the newborn \\
TTP & blood culture time to positivity \\
VLBW & very low birth weight \\
WBCs & white blood cells \\
\hline
\end{tabular}

\section{References}

1. Russell, A.R.B.; Kumar, R. Early onset neonatal sepsis: Diagnostic dilemmas and practical management. Arch. Dis. Child. Fetal Neonatal Ed. 2015, 100, F350-F354. [CrossRef] [PubMed]

2. Zea-Vera, A.; Ochoa, T.J. Challenges in the diagnosis and management of neonatal sepsis. J. Trop. Pediatrics 2015, 61, 1-13. [CrossRef] [PubMed]

3. Boettiger, M.; Tyer-Viola, L.; Hagan, J. Nurses' Early Recognition of Neonatal Sepsis. JOGNN 2017, 46, 834-845. [CrossRef] [PubMed]

4. Puopolo, K.M.; Escobar, G.J. Early-onset sepsis: A predictive model based on maternal risk factors. Curr. Opin. Pediatrics 2013, 25, 161-166. [CrossRef]

5. Sgro, M.; Yudin, M.H.; Lee, S.; Sankaran, K.; Tran, D.; Campbell, D. Early-onset neonatal sepsis: It is not only group B streptococcus. Paediatr. Child Health 2011, 16, 269. [CrossRef] 
6. Shim, G.H.; Kim, S.D.; Kim, H.S.; Kim, E.S.; Lee, H.J.; Lee, J.A.; Choi, C.W.; Kim, E.K.; Choi, E.H.; Kim, B.I.; et al. Trends in epidemiology of neonatal sepsis in a tertiary center in Korea: A 26-year longitudinal analysis, 1980-2005. J. Korean Med. Sci. 2011, 26, 284-289. [CrossRef]

7. Shah, B.A.; Padbury, J.F. Neonatal sepsis an old problem with new insights. Virulence 2014, 5, 170-178. [CrossRef]

8. Ershad, M.; Mostafa, A.; Dela Cruz, M.; Vearrier, D. Neonatal Sepsis. Curr. Emerg. Hosp. Med. Rep. 2019, 7, 83-90. [CrossRef]

9. Klingenberg, C.; Kornelisse, R.F.; Buonocore, G.; Maier, R.F.; Stocker, M. Culture-negative early-onset neonatal sepsis-At the crossroad between efficient sepsis care and antimicrobial stewardship. Front. Pediatrics 2018, 6, 285. [CrossRef]

10. Ng, S.; Strunk, T.; Jiang, P.; Muk, T.; Sangild, P.T.; Currie, A. Precision Medicine for Neonatal Sepsis. Front. Mol. Biosci. 2018, 5, 70. [CrossRef]

11. Cortese, F.; Scicchitano, P.; Gesualdo, M.; Filaninno, A.; De Giorgi, E.; Schettini, F.; Laforgia, N.; Ciccone, M.M. Early and Late Infections in Newborns: Where Do We Stand? A Review. Pediatrics Neonatol. 2016, 57, 265-273. [CrossRef] [PubMed]

12. Stipelman, C.H.; Smith, E.R.; Diaz-Ochu, M.; Spackman, J.; Stoddard, G.; Kawamoto, K.; Shakib, J.H. Early-onset sepsis risk calculator integration into an electronic health record in the nursery. Pediatrics 2019, 144, e20183464. [CrossRef] [PubMed]

13. Braye, K.; Foureur, M.; De Waal, K.; Jones, M.; Putt, E.; Ferguson, J. Epidemiology of neonatal early-onset sepsis in a geographically diverse Australian health district 2006-2016. PLoS ONE 2019, 14, e0214298. [CrossRef] [PubMed]

14. Aleem, S.; Greenberg, R.G. When to include a lumbar puncture in the evaluation for neonatal sepsis. Neoreviews 2019, 20, e124-e134. [CrossRef] [PubMed]

15. Arunachalam, A.R.; Pammi, M. Biomarkers in early-Onset Neonatal Sepsis: An Update. Ann. Clin. Med. Microbiol. 2015, 1, 1007.

16. Eschborn, S.; Weitkamp, J.H. Procalcitonin versus C-reactive protein: Review of kinetics and performance for diagnosis of neonatal sepsis. J. Perinatol. 2019, 39, 893-903. [CrossRef] [PubMed]

17. Stoll, B.J.; Hansen, N.I.; Sánchez, P.J.; Faix, R.G.; Poindexter, B.B.; Van Meurs, K.P.; Bizzarro, M.J.; Goldberg, R.N.; Frantz, I.D.; Hale, E.C.; et al. Early onset neonatal sepsis: The burden of group B streptococcal and E. coli disease continues. Pediatrics 2011, 127, 817-826. [CrossRef]

18. Gilfillan, M.; Bhandari, V. Biomarkers for the diagnosis of neonatal sepsis and necrotizing enterocolitis: Clinical practice guidelines. Early Hum. Dev. 2017, 105, 25-33. [CrossRef]

19. Stamatin, M.; Pǎduraru, L. Specific medical and ethical aspects in the care of life-Threatening illnesses in newborn. Rev. Rom. Bioet. 2009, 7, 67-73.

20. Odabasi, I.O.; Bulbul, A. Neonatal Sepsis. Sisli Etfal Hastan. Tip Bullet. 2020, 54, 142-158.

21. Research Kaiser Permanente Division of Neonatal Early-Onset Sepsis Calculator. Available online: https: //neonatalsepsiscalculator.kaiserpermanente.org/ (accessed on 25 July 2020).

22. Achten, N.B.; Klingenberg, C.; Benitz, W.E.; Stocker, M.; Schlapbach, L.J.; Giannoni, E.; Bokelaar, R.; Driessen, G.J.A.; Brodin, P.; Uthaya, S.; et al. Association of Use of the Neonatal Early-Onset Sepsis Calculator with Reduction in Antibiotic Therapy and Safety: A Systematic Review and Meta-analysis. JAMA Pediatrics 2019, 173, 1032-1040. [CrossRef] [PubMed]

23. Puopolo, K.M.; Benitz, W.E.; Zaoutis, T.E. Management of neonates born at $\geq 35$ 0/7 weeks' gestation with suspected or proven early-onset bacterial sepsis. Pediatrics 2018, 142, e20182894. [CrossRef] [PubMed]

24. Benitz, W.E.; Han, M.Y.; Madan, A.; Ramachandra, P. Serial serum C-reactive protein levels in the diagnosis of neonatal infection. Pediatrics 1998, 102, e41. [CrossRef] [PubMed]

25. Shane, A.L.; Sánchez, P.J.; Stoll, B.J. Neonatal sepsis. Lancet 2017, 390, 1770-1780. [CrossRef]

26. Dupuy, A.M.; Philippart, F.; Péan, Y.; Lasocki, S.; Charles, P.E.; Chalumeau, M.; Claessens, Y.E.; Quenot, J.P.; Gras-Le Guen, C.; Ruiz, S.; et al. Role of biomarkers in the management of antibiotic therapy: An expert panel review: I-Currently available biomarkers for clinical use in acute infections. Ann. Intensive Care 2013, 3, 1-8. [CrossRef]

27. Gandhi, P.; Kondekar, S. A Review of the Different Haematological Parameters and Biomarkers Used for Diagnosis of Neonatal Sepsis. EMJ Hematol. 2019, 7, 85-92. 
28. Chauhan, N.; Tiwari, S.; Jain, U. Potential biomarkers for effective screening of neonatal sepsis infections: An overview. Microb. Pathog. 2017, 107, 234-242. [CrossRef]

29. Sorsa, A. Diagnostic Significance of White Blood Cell Count and C-Reactive Protein in Neonatal Sepsis; Asella Referral Hospital, South East Ethiopia. Open Microbiol. J. 2018, 12, 209-217. [CrossRef]

30. Delanghe, J.R.; Speeckaert, M.M. Translational research and biomarkers in neonatal sepsis. Clin. Chim. Acta 2015, 451, 46-64. [CrossRef]

31. Bell, S.G. Procalcitonin and neonatal sepsis: Is this the biomarker we are looking for? Neonatal Netw. 2017, 36, 380-384. [CrossRef]

32. Boskabadi, H.; Zakerihamidi, M. Evaluate the diagnosis of neonatal sepsis by measuring interleukins: A systematic review. Pediatics. Neonatol. 2018, 59, 329-338. [CrossRef] [PubMed]

33. Sharma, A.; Thakur, A.; Bhardwaj, C.; Kler, N.; Garg, P.; Singh, M.; Choudhury, S. Potential biomarkers for diagnosing neonatal sepsis. Curr. Med. Res. Pract. 2020, 10, 12-17. [CrossRef]

34. Memar, M.Y.; Alizadeh, N.; Varshochi, M.; Kafil, H.S. Immunologic biomarkers for diagnostic of early-onset neonatal sepsis. J. Matern. Neonatal Med. 2019, 32, 143-153. [CrossRef] [PubMed]

35. Neal, S.R.; Musorowegomo, D.; Gannon, H.; Cortina Borja, M.; Heys, M.; Chimhini, G.; Fitzgerald, F. Clinical prediction models to diagnose neonatal sepsis: A scoping review protocol. BMJ Open 2020, 10, e039712. [CrossRef]

36. Wynn, J.L.; Wong, H.R.; Shanley, T.P.; Bizzarro, M.J.; Saiman, L.; Polin, R.A. Time for a neonatal-specific consensus definition for sepsis. Pediatrics Crit. Care Med. 2014, 15, 523-528. [CrossRef]

37. Ferrieri, P.; Wallen, L.D. Newborn Sepsis and Meningitis. In Avery's Diseases of the Newborn, 10th ed.; Gleason, C.A., Juul, S.E.B.T., Eds.; Elsevier Inc.: Philadelphia, PA, USA, 2018; pp. 553-565.e3, ISBN 9780323401722.

38. Dierig, A.; Berger, C.; Agyeman, P.K.A.; Bernhard-Stirnemann, S.; Giannoni, E.; Stocker, M.; Posfay-Barbe, K.M.; Niederer-Loher, A.; Kahlert, C.R.; Donas, A.; et al. Time-to-positivity of blood cultures in children with sepsis. Front. Pediatrics 2018, 6. [CrossRef]

39. Buttery, J.P. Blood cultures in newborns and children: Optimising an everyday test. Arch. Dis. Child. Fetal Neonatal Ed. 2002, 87, 25F-28F. [CrossRef]

40. Blackburn, R.M.; Muller-Pebody, B.; Planche, T.; Johnson, A.; Hopkins, S.; Sharland, M.; Kennea, N.; Heath, P.T. Neonatal sepsis-Many blood samples, few positive cultures: Implications for improving antibiotic prescribing. Arch. Dis. Child. Fetal Neonatal Ed. 2012, 97, 487-488. [CrossRef]

41. Brown, D.R.; Kutler, D.; Rai, B.; Chan, T.; Cohen, M. Bacterial concentration and blood volume required for a positive blood culture. J. Perinatol. 1995, 15, 157-159.

42. Garcia-Prats, J.A.; Cooper, T.R.; Schneider, V.F.; Stager, C.E.; Hansen, T.N. Rapid detection of microorganisms in blood cultures of newborn infants utilizing an automated blood culture system. Pediatrics 2000, 105, 523-527. [CrossRef]

43. Jardine, L.; Davies, M.W.; Faoagali, J. Incubation time required for neonatal blood cultures to become positive. J. Paediatr. Child Health 2006. [CrossRef] [PubMed]

44. Vamsi, S.R.; Bhat, R.Y.; Lewis, L.E.; Vandana, K.E. Time to positivity of blood cultures in neonates. Pediatics Infect. Dis. J. 2014, 33, 212-214. [CrossRef] [PubMed]

45. Giannoni, E.; Agyeman, P.K.A.; Stocker, M.; Posfay-Barbe, K.M.; Heininger, U.; Spycher, B.D.; Bernhard-Stirnemann, S.; Niederer-Loher, A.; Kahlert, C.R.; Donas, A.; et al. Neonatal Sepsis of Early Onset, and Hospital-Acquired and Community-Acquired Late Onset: A Prospective Population-Based Cohort Study. J. Pediatrics 2018, 201, 106-114.e4. [CrossRef] [PubMed]

46. Sarkar, S.S.; Bhagat, I.; Bhatt-Mehta, V.; Sarkar, S. Does maternal intrapartum antibiotic treatment prolong the incubation time required for blood cultures to become positive for infants with early-onset sepsis? Am. J. Perinatol. 2015, 32, 357-362. [CrossRef] [PubMed]

47. Pammi, M.; Flores, A.; Leeflang, M.; Versalovic, J. Molecular assays in the diagnosis of neonatal sepsis: A systematic review and meta-analysis. Pediatrics 2011, 128, e973-e985. [CrossRef]

48. Pammi, M.; Flores, A.; Versalovic, J.; Leeflang, M.M.G. Molecular assays for the diagnosis of sepsis in neonates. Cochrane Database Syst. Rev. 2017, 2, CD011926. [CrossRef]

49. Evans, R.W. Complications of lumbar puncture. Neurol. Clin. 1998, 16, 83-105. [CrossRef]

50. Williams, J.; Lye, D.C.B.; Umapathi, T. Diagnostic lumbar puncture: Minimizing complications. Intern. Med. J. 2008, 38, 587-591. [CrossRef] 
51. Polin, R.; Yoder, M. Workbook in Practical Neonatology, 5th ed.; Saunders: Philadelphia, PA, USA, 2015; ISBN 9781455774845.

52. Kanegaye, J.T.; Soliemanzadeh, P.; Bradley, J.S. Lumbar puncture in pediatric bacterial meningitis: Defining the time interval for recovery of cerebrospinal fluid pathogens after parenteral antibiotic pretreatment. Pediatrics 2001, 108, 1169-1174.

53. Srinivasan, L.; Harris, M.C.; Shah, S.S. Lumbar Puncture in the Neonate: Challenges in Decision Making and Interpretation. Semin. Perinatol. 2012, 36, 445-453. [CrossRef]

54. Greenberg, R.G.; Smith, P.B.; Cotten, C.M.; Moody, M.A.; Clark, R.H.; Benjamin, D.K. Traumatic lumbar punctures in neonates: Test performance of the cerebrospinal fluid white blood cell count. Pediatrics Infect. Dis. J. 2008, 27, 1047. [CrossRef] [PubMed]

55. Garges, H.P.; Anthony Moody, M.; Cotten, C.M.; Smith, P.B.; Tiffany, K.F.; Lenfestey, R.; Li, J.S.; Fowler, V.G.; Benjamin, D.K. Neonatal meningitis: What is the correlation among cerebrospinal fluid cultures, blood cultures, and cerebrospinal fluid parameters? Pediatrics 2006, 117, 1094-1100. [CrossRef] [PubMed]

56. Smith, P.B.; Garges, H.P.; Cotton, C.M.; Walsh, T.J.; Clark, R.H.; Benjamin, D.K. Meningitis in preterm neonates: Importance of cerebrospinal fluid parameters. Am. J. Perinatol. 2008, 25, 421-426. [CrossRef] [PubMed]

57. Sharma, D.; Farahbakhsh, N.; Shastri, S.; Sharma, P. Biomarkers for diagnosis of neonatal sepsis: A literature review. J. Matern. Neonatal Med. 2018, 31, 1646-1659. [CrossRef]

58. Iroh Tam, P.Y.; Bendel, C.M. Diagnostics for neonatal sepsis: Current approaches and future directions. Pediatrics Res. 2017, 82, 574-583. [CrossRef] [PubMed]

59. Ng, P.C.; Ma, T.P.Y.; Lam, H.S. The use of laboratory biomarkers for surveillance, diagnosis and prediction of clinical outcomes in neonatal sepsis and necrotising enterocolitis. Arch. Dis. Child. Fetal Neonatal Ed. 2015, 100, F448-F452. [CrossRef] [PubMed]

60. Xu, L.; Li, Q.; Mo, Z.; You, P. Diagnostic value of C-reactive protein in neonatal sepsis: A meta-analysis. Eur. J. Inflamm. 2016, 14, 100-108. [CrossRef]

61. Petel, D.; Winters, N.; Gore, G.C.; Papenburg, J.; Beltempo, M.; Lacroix, J.; Fontela, P.S. Use of C-reactive protein to tailor antibiotic use: A systematic review and meta-analysis. BMJ Open 2018, 8, e022133. [CrossRef]

62. Hofer, N.; Zacharias, E.; Müller, W.; Resch, B. An update on the use of C-reactive protein in early-Onset neonatal sepsis: Current insights and new tasks. Neonatology 2012, 102, 25-36. [CrossRef]

63. Mjelle, A.B.; Guthe, H.J.T.; Reigstad, H.; Bjørke-Monsen, A.L.; Markestad, T. Serum concentrations of C-reactive protein in healthy term-born Norwegian infants 48-72 hours after birth. Acta Paediatr. Int. J. Paediatr. 2019, 108, 849-854. [CrossRef]

64. Weitkamp, J.-H.; Aschner, J.L. Diagnostic Use of C-Reactive Protein (CRP) in Assessment of Neonatal Sepsis. Neoreviews 2005, 6, e508-e515. [CrossRef]

65. Reinhart, K.; Meisner, M.; Brunkhorst, F.M. Markers for Sepsis Diagnosis: What is Useful? Crit. Care Clin. 2006, 22, 503-519. [CrossRef] [PubMed]

66. Gilfillan, M.; Bhandari, V. Neonatal sepsis biomarkers: Where are we now? Res. Reports Neonatol. 2019, 9, 9-20. [CrossRef]

67. Perrone, S.; Lotti, F.; Longini, M.; Rossetti, A.; Bindi, I.; Bazzini, F.; Belvisi, E.; Sarnacchiaro, P.; Scapellato, C.; Buonocore, G. C reactive protein in healthy term newborns during the first 48 hours of life. Arch. Dis. Child. Fetal Neonatal Ed. 2018, 103, F163-F166. [CrossRef] [PubMed]

68. Rossum, A.M.C.V.; Wulkan, R.W.; Oudesluys-Murphy, A.M. Procalcitonin as an early marker of infection in neonates and children. Lancet Infect. Dis. 2004, 4, 620-630. [CrossRef]

69. Pontrelli, G.; De Crescenzo, F.; Buzzetti, R.; Jenkner, A.; Balduzzi, S.; Calò Carducci, F.; Amodio, D.; De Luca, M.; Chiurchiù, S.; Davies, E.H.; et al. Accuracy of serum procalcitonin for the diagnosis of sepsis in neonates and children with systemic inflammatory syndrome: A meta-analysis. BMC Infect. Dis. 2017, 17, 302. [CrossRef] [PubMed]

70. Patel, K.; McElvania, E. Diagnostic Challenges and Laboratory Considerations for Pediatric Sepsis. J. Appl. Lab. Med. 2019, 3, 587-600. [CrossRef]

71. Balog, A.; Ocsovszki, I.; Mándi, Y. Flow cytometric analysis of procalcitonin expression in human monocytes and granulocytes. Immunol. Lett. 2002, 84, 199-203. [CrossRef]

72. Christ-Crain, M.; Müller, B. Procalcitonin in bacterial infections-Hype, hope, more or less? Swiss Med. Wkly. 2005, 135, 451-460. 
73. Altunhan, H.; Annagür, A.; Örs, R.; Mehmetoĝlu, I. Procalcitonin measurement at 24hours of age may be helpful in the prompt diagnosis of early-onset neonatal sepsis. Int. J. Infect. Dis. 2011, 15, e854-e858. [CrossRef]

74. Assumma, M.; Signore, F.; Pacifico, L.; Rossi, N.; Osborn, J.F.; Chiesa, C. Serum procalcitonin concentrations in term delivering mothers and their healthy offspring: A longitudinal study. Clin. Chem. 2000, 46, 1583-1587. [CrossRef] [PubMed]

75. Chiesa, C.; Natale, F.; Pascone, R.; Osborn, J.F.; Pacifico, L.; Bonci, E.; De Curtis, M. C reactive protein and procalcitonin: Reference intervals for preterm and term newborns during the early neonatal period. Clin. Chim. Acta 2011, 412, 1053-1059. [CrossRef] [PubMed]

76. Fukuzumi, N.; Osawa, K.; Sato, I.; Iwatani, S.; Ishino, R.; Hayashi, N.; Iijima, K.; Saegusa, J.; Morioka, I. Age-specific percentile-based reference curve of serum procalcitonin concentrations in Japanese preterm infants. Sci. Rep. 2016, 6, 23871. [CrossRef] [PubMed]

77. Turner, D.; Hammerman, C.; Rudensky, B.; Schlesinger, Y.; Goia, C.; Schimmel, M.S. Procalcitonin in preterm infants during the first few days of life: Introducing an age related nomogram. Arch. Dis. Child. Fetal Neonatal Ed. 2006, 91, F283-F286. [CrossRef]

78. Chiesa, C.; Pellegrini, G.; Panero, A.; Osborn, J.F.; Signore, F.; Assumma, M.; Pacifico, L. C-reactive protein, interleukin-6, and procalcitonin in the immediate postnatal period: Influence of illness severity, risk status, antenatal and perinatal complications, and infection. Clin. Chem. 2003, 49, 60-68. [CrossRef]

79. Markic, J.; Saraga, M.; Dahlem, P. Sepsis Biomarkers in Neonates and Children: C-Reactive Protein and Procalcitonin. J. Child Sci. 2017, 7, 89-95. [CrossRef]

80. Stanciu, G.D.; Luca, A.; Rusu, R.N.; Bild, V.; Chiriac, S.I.B.; Solcan, C.; Bild, W.; Ababei, D.C. Alzheimer's disease pharmacotherapy in relation to cholinergic system involvement. Biomolecules 2020, 10, 40. [CrossRef]

81. Stanciu, G.D.; Ababei, D.C.; Bild, V.; Bild, W.; Paduraru, L.; Gutu, M.M.; Tamba, B.-I. Renal Contributions in the Pathophysiology and Neuropathological Substrates Shared by Chronic Kidney Disease and Alzheimer's Disease. Brain Sci. 2020, 10, 563. [CrossRef]

82. Stanciu, G.D.; Bild, V.; Ababei, D.C.; Rusu, R.N.; Cobzaru, A.; Paduraru, L.; Bulea, D. Link between Diabetes and Alzheimer's Disease Due to the Shared Amyloid Aggregation and Deposition Involving Both Neurodegenerative Changes and Neurovascular Damages. J. Clin. Med. 2020, 9, 1713. [CrossRef]

83. Ştefănescu, R.; Stanciu, G.D.; Luca, A.; Caba, I.C.; Tamba, B.I.; Mihai, C.T. Contributions of mass spectrometry to the identification of low molecular weight molecules able to reduce the toxicity of amyloid- $\beta$ peptide to cell cultures and transgenic mouse models of Alzheimer's disease. Molecules 2019, 24, 1167. [CrossRef]

84. Stefanescu, R.; Stanciu, G.D.; Luca, A.; Paduraru, L.; Tamba, B.-I. Secondary metabolites from plants possessing inhibitory properties against beta-amyloid aggregation as revealed by thioflavin-T assay and correlations with investigations on transgenic mouse models of Alzheimer's disease. Biomolecules 2020, 10, 870. [CrossRef] [PubMed]

85. Serban, D.; Anton, E.; Chirita, R.; Bild, V.; Ciobica, A.; Alexinschi, O.; Arcan, O.; Popescu, R.; Paduraru, L.; Timofte, D. Current aspects of the interactions between dementia, the brain renin-angiotensin system and oxidative stress. Arch. Biol. Sci. 2015, 67, 903-907. [CrossRef]

86. Arnon, S.; Litmanovitz, I.; Regev, R.H.; Bauer, S.; Shainkin-Kestenbaum, R.; Dolfin, T. Serum amyloid A: An early and accurate marker of neonatal early-onset sepsis. J. Perinatol. 2007, 27, 297-302. [CrossRef] [PubMed]

87. Elmashad, G.; Elsayed, H.; Omar, Z.; Badr, E.; Omran, O. Evaluation of serum amyloid A protein as a marker in neonatal sepsis. Menoufia Med. J. 2019, 32, 1094.

88. Hedegaard, S.S.; Wisborg, K.; Hvas, A.M. Diagnostic utility of biomarkers for neonatal sepsis-A systematic review. Infect. Dis. 2015, 47, 117-124. [CrossRef]

89. Chiesa, C.; Pacifico, L.; Natale, F.; Hofer, N.; Osborn, J.F.; Resch, B. Fetal and early neonatal interleukin-6 response. Cytokine 2015, 76, 1-12. [CrossRef]

90. Du Pont-Thibodeau, G.; Joyal, J.S.; Lacroix, J. Management of neonatal sepsis in term newborns. F1000Prime Rep. 2014, 6, 67. [CrossRef]

91. Ruan, L.; Chen, G.Y.; Liu, Z.; Zhao, Y.; Xu, G.Y.; Li, S.F.; Li, C.N.; Chen, L.S.; Tao, Z. The combination of procalcitonin and C-reactive protein or presepsin alone improves the accuracy of diagnosis of neonatal sepsis: A meta-analysis and systematic review. Crit. Care 2018, 22, 1-9. [CrossRef] 
92. Tzialla, C.; Manzoni, P.; Achille, C.; Bollani, L.; Stronati, M.; Borghesi, A. New Diagnostic Possibilities for Neonatal Sepsis. Am. J. Perinatol. 2018, 35, 575-577. [CrossRef]

93. Van Maldeghem, I.; Nusman, C.M.; Visser, D.H. Soluble CD14 subtype (sCD14-ST) as biomarker in neonatal early-onset sepsis and late-onset sepsis: A systematic review and meta-analysis. BMC Immunol. 2019, $20,17$. [CrossRef]

94. Bellos, I.; Fitrou, G.; Pergialiotis, V.; Thomakos, N.; Perrea, D.N.; Daskalakis, G. The diagnostic accuracy of presepsin in neonatal sepsis: A meta-analysis. Eur. J. Pediatrics 2018, 177, 625-632. [CrossRef] [PubMed]

95. Memar, M.Y.; Baghi, H.B. Presepsin: A promising biomarker for the detection of bacterial infections. Biomed. Pharmacother. 2019, 111, 649-656. [CrossRef] [PubMed]

96. Parri, N.; Trippella, G.; Lisi, C.; De Martino, M.; Galli, L.; Chiappini, E. Accuracy of presepsin in neonatal sepsis: Systematic review and meta-analysis. Expert Rev. Anti. Infect. Ther. 2019, 17, 223-232. [CrossRef] [PubMed]

97. Bechard, D.; Meignin, V.; Scherpereel, A.; Oudin, S.; Kervoaze, G.; Bertheau, P.; Janin, A.; Tonnel, A.B.; Lassalle, P. Characterization of the secreted form of endothelial-cell-specific molecule 1 by specific monoclonal antibodies. J. Vasc. Res. 2000, 37, 417-425. [CrossRef]

98. Pauly, D.; Hamed, S.; Behnes, M.; Lepiorz, D.; Lang, S.; Akin, I.; Borggrefe, M.; Bertsch, T.; Hoffmann, U. Endothelial cell-specific molecule-1/endocan: Diagnostic and prognostic value in patients suffering from severe sepsis and septic shock. J. Crit. Care 2016, 31, 68-75. [CrossRef]

99. Palud, A.; Parmentier-Decrucq, E.; Pastre, J.; De Freitas Caires, N.; Lassalle, P.; Mathieu, D. Evaluation of endothelial biomarkers as predictors of organ failures in septic shock patients. Cytokine 2015, 73, 213-218. [CrossRef]

100. Lassalle, P.; Molet, S.; Janin, A.; Van der Heyden, J.; Tavernier, J.; Fiers, W.; Devos, R.; Tonnel, A.B. ESM-1 is a novel human endothelial cell-specific molecule expressed in lung and regulated by cytokines. J. Biol. Chem. 1996, 271, 20458-20464. [CrossRef]

101. Béchard, D.; Scherpereel, A.; Hammad, H.; Gentina, T.; Tsicopoulos, A.; Aumercier, M.; Pestel, J.; Dessaint, J.-P.; Tonnel, A.-B.; Lassalle, P. Human Endothelial-Cell Specific Molecule-1 Binds Directly to the Integrin CD11a/CD18 (LFA-1) and Blocks Binding to Intercellular Adhesion Molecule-1. J. Immunol. 2001, 167, 3099-3106. [CrossRef]

102. Scherpereel, A.; Depontieu, F.; Grigoriu, B.; Cavestri, B.; Tsicopoulos, A.; Gentina, T.; Jourdain, M.; Pugin, J.; Tonnel, A.B.; Lassalle, P. Endocan, a new endothelial marker in human sepsis. Crit. Care Med. 2006, 34, 532-537. [CrossRef]

103. Mihajlovic, D.M.; Lendak, D.F.; Brkic, S.V.; Draskovic, B.G.; Mitic, G.P.; Novakov Mikic, A.S.; Cebovic, T.N. Endocan is useful biomarker of survival and severity in sepsis. Microvasc. Res. 2014, 93, 92-97. [CrossRef]

104. Pietrasanta, C.; Pugni, L.; Ronchi, A.; Bottino, I.; Ghirardi, B.; Sanchez-Schmitz, G.; Borriello, F.; Mosca, F.; Levy, O. Vascular Endothelium in Neonatal Sepsis: Basic Mechanisms and Translational Opportunities. Front. Pediatrics 2019, 7, 340. [CrossRef] [PubMed]

105. Buyuktiryaki, M.; Tayman, C.; Okur, N.; Serkant, U.; Cakir, U.; Halil, H.; Oncel, M.Y.; Oguz, S.S. Can Endocan Predict Late-Onset Neonatal Sepsis? J. Pediatrics Infect. Dis. 2019, 14, 96-102.

106. Zonda, G.I.; Zonda, R.; Cernomaz, A.T.; Păduraru, L.; Avasiloaiei, A.L.; Grigoriu, B.D. Endocan-A potential diagnostic marker for early onset sepsis in neonates. J. Infect. Dev. Ctries. 2019, 13, 311-317. [CrossRef] [PubMed]

107. Zonda, G.I.; Zonda, R.; Cernomaz, A.T.; Paduraru, L.; Grigoriu, B.D. Endocan serum concentration in uninfected newborn infants. J. Infect. Dev. Ctries. 2019, 13, 817-822. [CrossRef]

108. Shi, J.; Tang, J.; Chen, D. Meta-analysis of diagnostic accuracy of neutrophil CD64 for neonatal sepsis. Ital. J. Pediatrics 2016, 42, 1-9. [CrossRef]

109. Qiu, X.; Li, J.; Yang, X.; Tang, J.; Shi, J.; Tong, Y.; Qu, Y.; Mu, D. Is neutrophil CD11b a special marker for the early diagnosis of sepsis in neonates A systematic review and meta-analysis. BMJ Open 2019, 9, e025222. [CrossRef]

110. Stålhammar, M.E.; Sindelar, R.; Douhan Håkansson, L. Neutrophil Receptor Response to Bacterial N-formyl Peptides is Similar in Term Newborn Infants and Adults in Contrast to IL-8. Scand. J. Immunol. 2016, 84, 332-337. [CrossRef] 
111. Markic, J.; Jeroncic, A.; Polancec, D.; Bosnjak, N.; Markotic, A.; Mestrovic, J.; Culic, V.C. CD15s is a potential biomarker of serious bacterial infection in infants admitted to hospital. Eur. J. Pediatrics 2013, 172, 1363-1369. [CrossRef]

112. Eggimann, P.; Que, Y.A.; Rebeaud, F. Measurement of pancreatic stone protein in the identification and management of sepsis. Biomark. Med. 2019, 13, 135-145. [CrossRef]

113. ELMeneza, S.; Fouad, R.; El Bagoury, I. Pancreatic stone protein as a novel marker for early onset neonatal sepsis. Edelweiss Pediatrics J. 2019, 1, 1-4.

114. Rass, A.A.; Talat, M.A.; Arafa, M.A.; El-Saadany, H.F.; Amin, E.K.; Abdelsalam, M.M.; Mansour, M.A.; Khalifa, N.A.; Kamel, L.M. The Role of Pancreatic Stone Protein in Diagnosis of Early Onset Neonatal Sepsis. Biomed. Res. Int. 2016, 2016, 1035856-1035858. [CrossRef] [PubMed]

115. Schlapbach, L.J.; Graf, R.; Woerner, A.; Fontana, M.; Zimmermann-Baer, U.; Glauser, D.; Giannoni, E.; Roger, T.; Müller, C.; Nelle, M.; et al. Pancreatic stone protein as a novel marker for neonatal sepsis. Intensive Care Med. 2013, 39, 754-763. [CrossRef] [PubMed]

116. Benninga, R.; van den Bogaard, P.; Rebeaud, F. Abionic's PSP 'sepsis test' on the abioSCOPEßdevice: 5 minutes to save lives Romy. Abionic SA 2019, 34, 123-135.

117. Zhang, X.; Sun, C.; Li, J. Serum sICAM-1 and PCT levels and their prognostic value in neonates with sepsis. Int. J. Clin. Exp. Med. 2019, 12, 5874-5880.

118. Zonneveld, R.; Martinelli, R.; Shapiro, N.I.; Kuijpers, T.W.; Plötz, F.B.; Carman, C.V. Soluble adhesion molecules as markers for sepsis and the potential pathophysiological discrepancy in neonates, children and adults. Crit. Care 2014, 18, 204. [CrossRef]

119. Achten, N.B.; Van Meurs, M.; Jongman, R.M.; Juliana, A.; Molema, G.; Plötz, F.B.; Zonneveld, R. Markers of endothelial cell activation in suspected late onset neonatal sepsis in Surinamese newborns: A pilot study. Transl. Pediatrics 2019, 8, 412-418. [CrossRef]

120. Zonneveld, R.; Jongman, R.M.; Juliana, A.; Molema, G.; Van Meurs, M.; Plötz, F.B. Serum concentrations of endothelial cell adhesion molecules and their shedding enzymes and early onset sepsis in newborns in Suriname. BMJ Paediatr. Open 2018, 2, e000312. [CrossRef]

121. Edgar, J.D.M.; Gabriel, V.; Gallimore, J.R.; McMillan, S.A.; Grant, J. A prospective study of the sensitivity, specificity and diagnostic performance of soluble intercellular adhesion molecule 1, highly sensitive C-reactive protein, soluble E-selectin and serum amyloid A in the diagnosis of neonatal infection. BMC Pediatrics 2010, 10, 252. [CrossRef]

122. El-Mashad, G.; El-Sayed, H.; Salem, O. Serum leptin level as a marker of neonatal sepsis. Menoufia Med. J. 2016, 29, 252.

123. Rao, L.; Song, Z.; Yu, X.; Tu, Q.; He, Y.; Luo, Y.; Yin, Y.; Chen, D. Progranulin as a novel biomarker in diagnosis of early-onset neonatal sepsis. Cytokine 2020, 128, 155000. [CrossRef]

124. Sayed El Nemer, F. Serum Neopterin Level in Early Onset Neonatal Sepsis. Am. J. Biosci. 2015, 3, 80. [CrossRef]

125. Ozdemir, A.A.; Elgormus, Y. Value of Resistin in Early Onset Neonatal Sepsis. J. Child Sci. 2017, 7, e146-e150. [CrossRef]

126. Saboktakin, L.; Bilan, N.; Behbahan, A.G.; Poorebrahim, S. Relationship between resistin levels and sepsis among children under 12 years of age: A case control study. Front. Pediatrics 2019, 7, 7. [CrossRef] [PubMed]

127. Tunç, T.; Polat, A.; Özdemir, R.; Kiliçaslan, B.; Can, E.; Çelik, H.T.; Arsan, S.; Kader, S.; Erol, S.; Uslu, S.; et al. Assessment of novel biomarkers: STREM-1, pentraxin-3 and pro-adrenomedullin in the early diagnosis of neonatal early onset sepsis. J. Neonatal. Perinatal. Med. 2020, 13, 39-45. [CrossRef] [PubMed]

128. Haque, K. Journey from Cell count to Metabolomics in the diagnosis of Neonatal Sepsis. Asia Pac. J. Paediatr. Child Health 2018, 2, 1-10.

129. National Institute for Health and Care Excellence Clinical Guideline: Preoperative Tests. Economic Considerations for Delphi. Available online: https://www.nice.org.uk/guidance/ng45/evidence/appendix-meconomic-considerations-for-delphi-pdf-87258149464 (accessed on 4 August 2020).

130. Southern CommunityLaboratories Commercial/Clinical Trial Test Price List (incl GST). Available online: https://www.otago.ac.nz/health-research-south/authorisation/otago693340.pdf (accessed on 1 July 2020).

131. Zwang, O.; Albert, R.K. Analysis of strategies to improve cost effectiveness of blood cultures. J. Hosp. Med. 2006, 1, 272-276. [CrossRef] [PubMed] 
132. Oppong, R.; Jit, M.; Smith, R.D.; Butler, C.C.; Melbye, H.; Mölstad, S.; Coast, J. Cost-effectiveness of point-of-care C-reactive protein testing to inform antibiotic prescribing decisions. Br. J. Gen. Pract. 2013, 63, e465-e471. [CrossRef]

133. Kip, M.M.A.; Van Oers, J.A.; Shajiei, A.; Beishuizen, A.; Berghuis, A.M.S.; Girbes, A.R.; De Jong, E.; De Lange, D.W.; Nijsten, M.W.N.; Ijzerman, M.J.; et al. Cost-effectiveness of procalcitonin testing to guide antibiotic treatment duration in critically ill patients: Results from a randomised controlled multicentre trial in the Netherlands 11 Medical and Health Sciences 1117 Public Health and Health Services. Crit. Care 2018, 22, 1-20.

134. Price List of Laboratory Tests-Medirex. Available online: https:/www.laboratornadiagnostika.sk/source/ download/medirex_pricelist.pdf (accessed on 1 April 2020).

135. Synevo Laboratory. Available online: https://www.synevo.ro/shop/interleukina-6/(accessed on 4 August 2020).

136. Elabscience-Mybiosource. Available online: https://www.elabscience.com/?gclid= EAIaIQobChMI3emC39zb7QIVTFXVCh1aMwaYEAAYAiAAEgJOu_D_BwE (accessed on 1 August 2020).

137. Sinha, M.; Jupe, J.; Mack, H.; Coleman, T.P.; Lawrence, S.M.; Fraley, S.I. Emerging technologies for molecular diagnosis of sepsis. Clin. Microbiol. Rev. 2018, 31, e00089-17. [CrossRef]

Publisher's Note: MDPI stays neutral with regard to jurisdictional claims in published maps and institutional affiliations.

(C) 2020 by the authors. Licensee MDPI, Basel, Switzerland. This article is an open access article distributed under the terms and conditions of the Creative Commons Attribution (CC BY) license (http://creativecommons.org/licenses/by/4.0/). 